\title{
Biomedical Applications of Electrospun Nanofibers: Drug and Nanoparticle Delivery
}

\author{
Rajan Sharma Bhattarai ${ }^{1}$ (), Rinda Devi Bachu ${ }^{1}$, Sai H. S. Boddu ${ }^{2, *}$ and Sarit Bhaduri ${ }^{3,4}$ \\ 1 College of Pharmacy and Pharmaceutical Sciences, The University of Toledo Health Science Campus, Toledo, \\ OH 43614, USA; RajanSharma.Bhattarai@rockets.utoledo.edu (R.S.B.); \\ RindaDevi.Bachu@rockets.utoledo.edu (R.D.B.) \\ 2 Department of Pharmaceutical Sciences, College of Pharmacy and Health Sciences, Ajman University, \\ Ajman 2758, UAE \\ 3 Department of Mechanical, Industrial and Manufacturing Engineering, University of Toledo, Toledo, \\ OH 43614, USA; Sarit.Bhaduri@utoledo.edu \\ 4 Department of Surgery (Dentistry), University of Toledo, Toledo, OH 43614, USA \\ * Correspondence: s.boddu@ajman.ac.ae; Tel.: +971-6-705-6345
}

Received: 20 September 2018; Accepted: 26 October 2018; Published: 24 December 2018

\begin{abstract}
The electrospinning process has gained popularity due to its ease of use, simplicity and diverse applications. The properties of electrospun fibers can be controlled by modifying either process variables (e.g., applied voltage, solution flow rate, and distance between charged capillary and collector) or polymeric solution properties (e.g., concentration, molecular weight, viscosity, surface tension, solvent volatility, conductivity, and surface charge density). However, many variables affecting electrospinning are interdependent. An optimized electrospinning process is one in which these parameters remain constant and continuously produce nanofibers consistent in physicochemical properties. In addition, nozzle configurations, such as single nozzle, coaxial, multi-jet electrospinning, have an impact on the fiber characteristics. The polymeric solution could be aqueous, a polymeric melt or an emulsion, which in turn leads to different types of nanofiber formation. Nanofiber properties can also be modified by polarity inversion and by varying the collector design. The active moiety is incorporated into polymeric fibers by blending, surface modification or emulsion formation. The nanofibers can be further modified to deliver multiple drugs, and multilayer polymer coating allows sustained release of the incorporated active moiety. Electrospun nanofibers prepared from polymers are used to deliver antibiotic and anticancer agents, DNA, RNA, proteins and growth factors. This review provides a compilation of studies involving the use of electrospun fibers in biomedical applications with emphasis on nanoparticle-impregnated nanofibers.
\end{abstract}

Keywords: electrospinning; parameters; drug delivery; applications

\section{Electrospinning and Its History}

Electrospinning is a process of forming micro/nanometer-sized polymeric fibers, either hollow or solid, with the application of the electric force on the polymeric solution at the tip of a conducting tube. It is one of the most commonly used techniques to obtain continuous fibers in the nanometer size range [1-3]. Electrospinning, also known as electrostatic spinning, has been used extensively for over three decades, and its usefulness in the fields of science and technology is still on the increase. Bose et al. first described the aerosols generated by the application of electric potential to the fluids in 1745 [4]. Further, Lord Rayleigh studied the amount of charge needed by the fluid to overcome the surface tension of a drop. Cooley and Morton patented the first device to spray the liquids under the influence of electrical charge in 1902 and 1903, and the fabrication of artificial silk was undertaken by 
Kiyohito et al. in 1929 [4]. Studies in the 1940s, 1950s and 1960s were limited and mainly focused on obtaining uniform-sized particle/fibers, decreasing the size, understanding and optimizing parameters, and designing the instruments $[5,6]$. In the 1990s, the process was finally taken up by educational institutions and, since then, many studies have been carried out on the versatility of manufacturing and the applications of the electrospun particles [2].

\subsection{Process of Electrospinning}

The electrospinning process involves the use of a very high voltage source (of either positive or negative polarity) to charge the polymer solution or melt, a grounded collector, and a syringe pump (Figure 1). It is advisable to perform the electrospinning process in a closed hood with minimal atmospheric influence, which serves as a safety measure for fibers and for the personnel. When a sufficient repulsive charge is accumulated and the repulsive force is equal to the surface tension, the drop surface on the conducting tube starts to form a cone called a Taylor cone. The conducting polymer solution/melt can exist in an equilibrium cone form under the influence of the electric field at an angle of $49.3^{\circ}$ [7]. If the electric field is increased further, the repulsive force overcomes the surface tension. This results in the formation of a liquid jet from the Taylor cone when there is sufficient attraction between the molecules in the solution/melt. If the solution does not have sufficient cohesive attraction, the jets break and the resulting particles are sprayed onto a collector plate. The fiber originating from the Taylor cone travels through the air towards the collector plate, and during the process, the solvent evaporates, leading to a solid fiber deposit onto the collector plate [6,7]. The jet starts to experience instability after traveling through the air for a short distance and then starts to whip, thus increasing the path distance to the collector. This process assists in fiber thinning and solvent evaporation. There are multiple theories proposed on the reason behind jet instability. Some of the prominent theories include: repulsive interaction of charges in the polymer jet [8]; increase in charge density during jet thinning, thus increasing radial charge repulsion to cause jet splitting at a critical charge density [9]; and, "whipping" instability (spiraling loops) [10], causing the fiber to turn, bend [11] and/or splay [12]. Shin et al. have suggested the whipping stability concept based on the results obtained using high-speed photography, where a single strand of jet whipped very fast to give a cone-like appearance [11]. The "inverted cone" appearance had long been misunderstood as a splitting of the jet midway through its travel in the air.

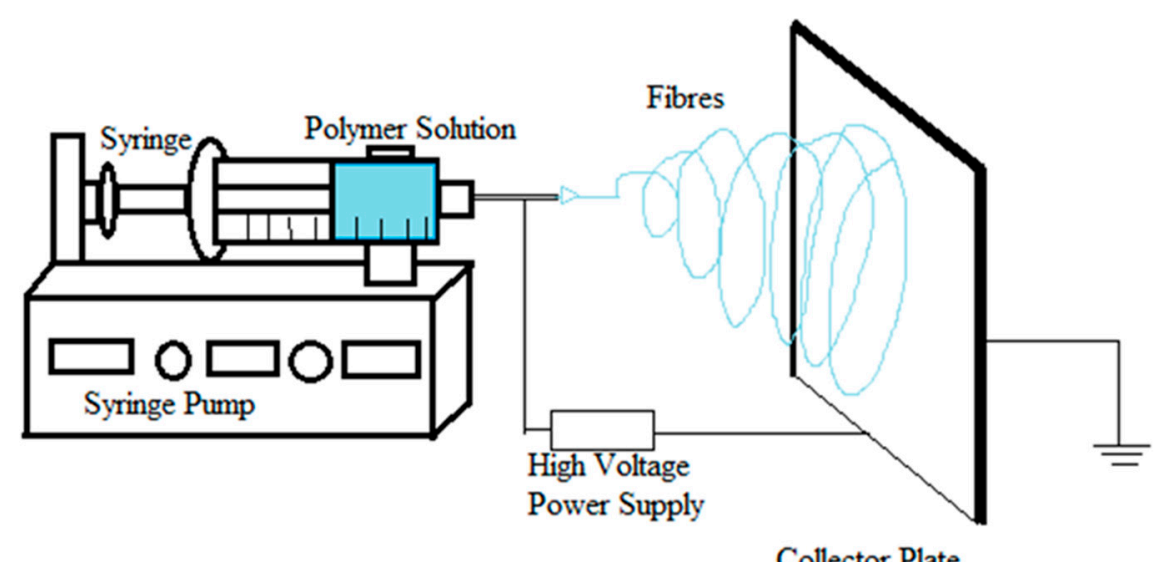

Figure 1. Schematic of electrospinning system. The system consists of polymer solution/melt in a syringe, mounted on a syringe pump, operating at a constant slow speed. High voltage direct current supply is connected to the needle of the syringe to charge the fluid. With sufficient voltage, the fluid forms a Taylor cone and then jet erupts from the cone towards the collector plate with whipping instability. 


\subsection{Physics of Electrospinning}

When the electric field/voltage is increased gradually and the surface of the drop becomes convex at a certain voltage, $V_{c}$ (critical voltage) is reached. At $V_{c}$, the jets (electrospinning) and sprays (electrospraying) begin, which are represented by Equation (1):

$$
V_{c}=4 \frac{H^{2}}{L^{2}}\left(\operatorname{Ln} \frac{2 L}{R}-\frac{3}{2}\right)(0.117 \pi \gamma R)
$$

where $H$ is the separation between capillary and the collector, $L$ is the length of capillary, $R$ is the radius of capillary and $\gamma$ is the surface tension [7]. This relationship was identified by Taylor, and a similar relationship for the potential required for the electrospraying of charged pendant drops of solutions from the pendant in a capillary tube was established by Hendrick et al., in Equation (2) [13,14]:

$$
V=300 \sqrt{20 \pi \gamma \mathrm{r}}
$$

where, $V$ is the required voltage, $\gamma$ is the surface tension and $\mathrm{r}$ is the radius of the pendant drop. Even though viscosity and conductivity are vital in the electrospinning process, they are missing from the equation. The use of applied voltage and the surface tension gives a representative equation for slightly conducting, medium- to low-conductivity solutions [14].

\section{Parameters of Electrospinning}

The electrospinning process is simple and does not involve heavy machinery. The processing parameters and solution parameters affect the size, porosity and uniformity of the fibers. These parameters have been discussed individually; however, the observations made in any particular study by a team of researchers are not universal. The modification of a parameter in one polymer may produce a totally different result with another polymer. In addition, none of the parameters act independently during the electrospinning process, and the final fibers are the result of a combination of several parameters.

\subsection{Process-Related Parameters of Electrospinning}

\subsubsection{Applied Voltage}

The primary factor influencing the formation of fibers is the strength of the applied DC voltage. The size of the fiber, formation of beads and absence of jet formation are all dependent on the applied $\mathrm{DC}$ voltage. With an increase in the applied voltage of a polyethylene oxide (PEO)/water system, the originating site for the jet changes from the tip of the pendant drop to the tip of the capillary, and the volume of the pendant drop decreases gradually (Figure 2). When the fiber is formed from within the capillary, the bead defects in the fiber increase [6,15]. A reduction in voltage up to some range moves the splaying (instability) point towards the tip of the capillary (i.e., the jet becomes unstable earlier) [12]. A study by Reneker and Chun reported no significant change in the fiber diameter with a change in the electric field with PEO solution [16]. On the other hand, electrospun polyvinyl alcohol (PVA)/water solution exhibited a broad diameter distribution above $10 \mathrm{kV}$ [17,18]. In another study, Megelski et al. observed an increase in fiber size of polystyrene with a decrease in spinning voltage and with no significant change in the pore formation in fibers [19]. 


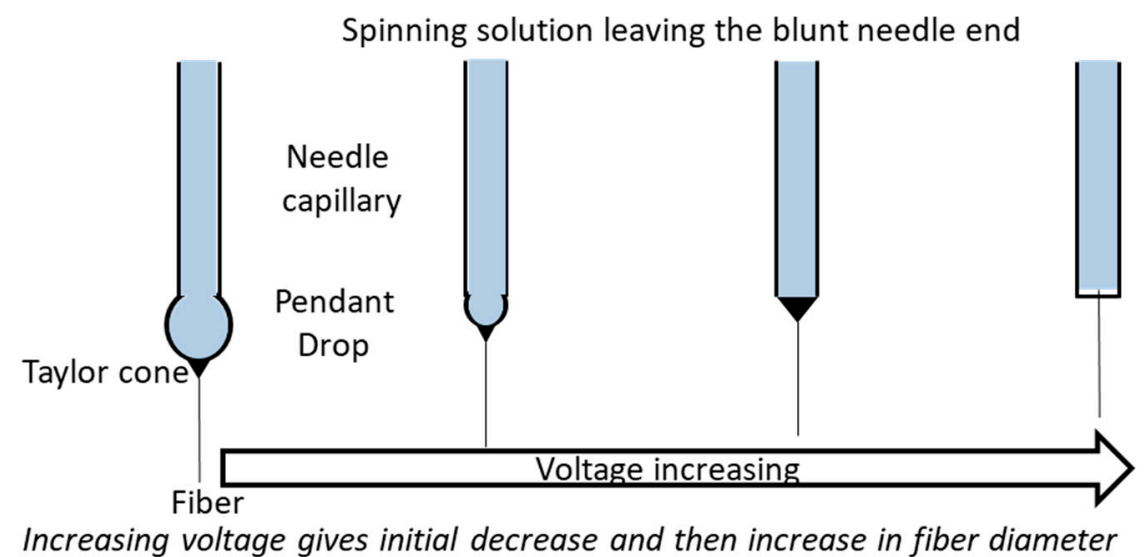

Figure 2. The effect of applied electric field on Taylor cone formation (dark colored tip). At low electric field, pendant drop is formed at the tip of the capillary and then a cone is formed on the tip. When the applied voltage is increased gradually, the drop size decreases until just a cone is formed at the tip of the capillary. If the voltage is further increased, fiber formation starts from within the needle without forming a visible Taylor cone on the blunt tip of the needle.

The fibers formed during the electrospinning process transport the charge to the grounded collector plate to close the circuit. This allows the electric current associated with the process to be measured; it is small (high voltage, 10-15 kV, high resistance and therefore very low current). When conductivity, dielectric constant and flow rate through the pump remain the same, an increase in current indicates an increase in the mass of the fibers formed. During the electrospinning process, the increase in current is gradual at first and then increases sharply from one voltage point, while sharp, steep increases are observed during electrospraying. The point of a sharp change in current could be indicative of the defect/change in the bead density [15].

Studies on the reversal of polarity obtained by grounding the solution in capillary and charging the collects resulted in inconsistent findings. Kilic et al. studied the effect of polarity on the electrospinning process of $7.5 \mathrm{wt} \%$ poly(vinyl alcohol)/water solution on production efficiency and nanofiber morphology. They concluded that due to the lack of columbic force acting on the polymer jet, the new reversed setup resulted in less nanofiber production. They also reported that the diameter and pore size of the web layer were much finer and more homogeneously distributed in the conventional setup [20]. On the other hand, Varesano et al. reported the production of good quality nanofibers with multi-jet electrospinning using both conventional and reverse polarity [21].

\subsubsection{Flow Rate}

The polymer flow rate has a direct impact on the size, shape and porosity of electrospun fibers. A study on polystyrene/tetrahydrofuran (THF) solutions by Megelski et al. reported an increased fiber diameter and pore size with flow rate. However, at high flow rates, bead defects and flat, ribbon-like structures were observed due to insufficient drying [19]. In a different study, a similar effect on fiber morphology was observed with a $20 \mathrm{wt} \%$ solution of nylon 6 in formic acid at a constant electric field of $20 \mathrm{kV}$ at flow rates of $0.1,0.5,1$ and $1.5 \mathrm{~mL} / \mathrm{h}$. An optimal flow rate of $0.5 \mathrm{~mL} / \mathrm{h}$ resulted in fibers with the narrowest fiber diameter distribution and a stable Taylor cone. However, at a flow rate of $0.1 \mathrm{~mL} / \mathrm{h}$, the Taylor cone could not be maintained and reduced over time to obtain fiber from within the capillary tip. At flow rates of $1.0 \mathrm{~mL} / \mathrm{h}$ and $1.5 \mathrm{~mL} / \mathrm{h}$, the electric field was not sufficient to spin all the solution, and only a few drops were sprayed as they broke off from the capillary due to the gravitational force [22]. 


\subsubsection{Capillary-Collector Distance}

The distance between the capillary and the collector is another factor which plays a significant role in controlling the size and morphology of the nanofibers [23]. This distance needs to be optimized as it might be the factor that distinguishes electrospraying and electrospinning. Typically a distance ranging from 10 to $20 \mathrm{~cm}$ is considered to be an effective spinning distance with the conventional method of electrospinning [24]. According to Doshi and Reneker, the larger the distance from the Taylor cone, the smaller the fiber diameter [9]. Jaeger et al. reported a decrease in fiber diameter $(19 \mu \mathrm{m}$, $11 \mu \mathrm{m}$ and $9 \mu \mathrm{m})$ with increasing distance $(1 \mathrm{~cm}, 2 \mathrm{~cm}$ and $3.5 \mathrm{~cm})$ from the orifice [12]. In another study investigating the electrospun polystyrene polymer fibers, decreasing the distance between the capillary and the collector from $35 \mathrm{~cm}$ to $30 \mathrm{~cm}$ did not change the diameter of the fibers significantly; however it led to the formation of non-homogeneous and elongated beads [19].

\subsection{Solution-Related Parameters of Electrospinning}

\subsubsection{Concentration of Solution}

Viscosity and surface tension, which determine the spinnability of a solution, should be taken into consideration in determining the concentration of solution/melt for electrospinning. Surface tension is a dominating factor in a low concentration solution (low viscosity, $<1$ poise), and at such concentration, drops will be formed instead of a continuous fiber. At a higher concentration (viscosity $>20$ poise), the flow of the solution cannot be controlled and maintained. In the PEO/water study discussed above in Section 2.1.1, a concentration range of $4-10 \mathrm{wt} \%$ with viscosity and surface tension ranging between 1-20 poise and 55-35 dynes/cm, respectively, were studied. At low concentrations of 4\%, fibers were not sufficiently dry and formed fiber junctions and bundles. At higher concentrations, straight and cylindrical fibers with fewer fiber junctions and bundles were reported. The diameter of the electrospun PEO fibers increased with concentration, and a bimodal size distribution was observed above $7 \mathrm{wt} \%$ concentration. The average diameter of the fibers was reported to be related to solution concentration through the power law relationship, with an exponent of 0.5 [15]. A statistical study by Sukigara et al. on regenerated silk proved that the silk concentration was the most important parameter in producing uniform fibers of a diameter less than $100 \mathrm{~nm}$ [25]. Fong et al. investigated the effect of viscosity on morphology defects (bead formation) of electrospun nanofibers formed from PEO solutions. An increase in bead diameter and decrease in bead density was observed with solution viscosity. At higher viscosity, the shape of beads changed from spherical to spindle resulting in the formation of nanofibers with diminished morphology defects [26]. Solutions with low polymer concentration and high surface tension produced droplets as the viscoelastic forces could not overcome the repulsive forces of charge, resulting in the fragmentation of fiber jet into droplets. At higher concentrations, the viscoelastic forces are sufficient to prevent the fragmentation resulting in the formation of smooth nanofibers. Nanofibers of polyacrylonitrile solutions were formed in the viscosity range of 1.7 to 215 centipoise. With increase in viscosity, the fiber jet length and the nanofiber diameter increased and the drop at the capillary tip changed from hemispherical to conical shape [27]. In a different study, 15 and $20 \% w / v$ solutions of poly(desaminotyrosyl-tyrosine ethyl ester carbonate) (poly(DTE carbonate)) were electrospun at a voltage of $10 \mathrm{kV}$ to $25 \mathrm{kV}$ at $10 \mathrm{~cm}$ distance. Beaded fibers were observed during electrospinning at a lower concentration solution until the voltage reached $20 \mathrm{kV}$, and the density of beads decreased until the voltage reached $15 \mathrm{kV}$; average fiber diameter increased, while increasing the voltage from $20 \mathrm{kV}$ to $25 \mathrm{kV}$. At higher solution concentrations, the smooth fibers obtained showed an increasing diameter and decreasing fiber density with the increase in the electric field from $10 \mathrm{kV}$ to $25 \mathrm{kV}$ [28].

\subsubsection{Molecular Weight}

The molecular weight of polymer influences the solution viscosity and thus has an important effect on fiber morphology. For example, decreasing the molecular weight of poly(vinyl alcohol) 
while maintaining other parameters constant resulted in the formation of bead-like structures. On the other hand, higher molecular weight resulted in smooth fibers initially followed by ribbon-like fibers upon further increase in molecular weight [29]. Ultra-high molecular weight polymers, such as polyacrylamide (molecular weight $9 \times 10^{6} \mathrm{~g} / \mathrm{mol}$ ), exhibited a variety of fiber morphologies even with a minute change in the concentration within the range 0.3-3.0 $\mathrm{wt} \%$. Beaded and smooth fibers were formed at concentrations between 0.3 to $0.7 \mathrm{wt} \%$, whereas smooth fibers with ribbons coexisted at 0.7 to $2 \mathrm{wt} \%$. Above $2.0 \mathrm{wt} \%$, only ribbons were formed, which were either helical or zigzag with triangular beads on them [30]. Additionally, a study on the melts of polypropylene with varying molecular weights showed an increase in the fiber diameter with molecular weight. High molecular weight polymers show the highest degree of entanglement and pose difficulties for the electric field to pull on individual polymer chains to obtain a thin fiber [31].

\subsubsection{Solution Viscosity}

Viscosity determines the solution's ability to form fibers. Smooth continuous fibers can be obtained at optimum viscosity for a particular polymer solvent combination. The viscosity, molecular weight of the polymer and polymer concentration are interrelated, and one cannot be independently judged. Low viscosity fails to form the fibers, while high viscosity requires a higher electric field for electrospinning, making it hard to operate [25,32]. Baumgarten observed the formation of fine droplets at a lower viscosity and with incomplete drying. At higher viscosity, the droplets bumped into each other in mid-air due to incomplete drying with acrylic polymer [27]. When a solution has low viscosity, surface tension dominates the process of fiber formation, but at optimum concentration, it is the combined effect of both parameters [29,33-36]. Yang et al. suggested a mixed solvent system of dimethylformamide (DMF) and ethanol (50:50) for obtaining the best electrospun fibers of poly(vinyl pyrrolidone) and attributed the success to the combined effect of solution viscosity and charge density [10].

\subsubsection{Surface Tension of the Solution}

Surface tension is the measure of cohesive forces between the molecules in solution form and is dependent upon the solution composition, polymer and solvent(s) used. Yang et al. studied the influence of solvents on the formation of nanofibers with poly(vinyl pyrrolidone) and concluded that lower surface tension with high viscosity formed smooth nanofibers with ethanol as the solvent. They proposed the use of a multi-solvent system to obtain optimum surface tension and viscosity parameters for better electrospun fibers [10]. Like viscosity, surface tension can define the range of solvents and concentrations to be used in the electrospinning process [18].

\subsubsection{Conductivity and Surface Charge Density}

The impact of conductivity and surface charge density of solution also plays an important role in the process of electrospinning. It is important to have high conductivity for a greater charge-carrying capacity. A highly conductive solution experiences a stronger tensile force in an electric field compared to the less conductive solution, making the former preferable for electrospinning. An increase in the conductivity of the solution causes a substantial decrease in the diameter of the nanofibers. The radius of the fiber jet varies inversely as the cube root of the conductivity of solution [37]. For preparation of acrylic microfibers, Baumgarten reported that the jet radius is dependent on the inverse cube root of electric conductivity [27]. Natural polymers, being polyelectrolytic, have better charge-carrying ability and lead to poor fiber formation compared to synthetic polymers [38]. Hayati et al. observed that stable jets could be obtained by semi-conducting liquids by applying sufficient voltage. Due to insufficient free charges, the insulating liquids, such as paraffin oil, could not build an electrostatic charge on the surface, while highly conducting water produced an unstable stream and sparking at higher electric fields. Consequently, insulating liquids and semiconducting liquids could produce stable fibers [39]. Yet another study on poly(vinyl alcohol) solution showed that the addition of 
a small amount of sodium chloride drastically increased the conductivity and decreased the fiber diameter [17]. The addition of sodium chloride has an effect on decreasing the occurrence of beads in PEO solution [26]. Sodium phosphate [38], potassium phosphate [38], ammonium chloride [26], and lithium chloride [26] are also used to obtain better fibers by changing the conductivity of solutions. Huang et al. used compounds soluble in organic solvents, such as pyridine, that react with formic acid in solution to form a salt. Pyridine improves the conductivity and can easily be removed to obtain dry fibers. The addition of $0.4 \mathrm{wt} \%$ of pyridine doubled the electrical conductivity of $2 \%$ nylon- $4,6 \mathrm{in}$ formic acid [40].

\subsubsection{Solvent Volatility}

The distance between the tip of the capillary and the collector is only a few centimeters (typically $10-15 \mathrm{~cm}$ ), and the path taken by the jet to reach the collector is a few folds more. The fibers formed during the process are porous and dry fast, depending on the choice of the solvent used for solubilization of the polymer. The insufficiently dried fiber may attach to itself mid-air [27], form ribbon-like fibers [19] or attach to itself after depositing on the collector. A study on polystyrene fibers showed that the use of more volatile tetrahydrofuran (THF) as a solvent produced high-density pores and increased the surface area of fibers by up to $40 \%$. The same polymer in DMF lost the microtexture completely. A combination of these solvents in different ratios gave different morphology profiles as the volatility of the mixture varied [19].

\section{Types of Electrospinning}

The type of electrospinning process can have a significant impact on fiber formation in addition to the process and solution parameters. Two main aspects to deal with in the type of electrospinning are solution vs. melt electrospinning and nozzle configuration [6].

\subsection{Solution vs. Melt vs. Emulsion Electrospinning}

Electrospun fibers are generally obtained from polymer solutions or melts or emulsions. Melt spinning has high-throughput rate and process safety; solutions have the advantage of using a large variety of polymeric materials, lower energy consumption and superior mechanical, optical and electrical properties of prepared fibers. Emulsion electrospinning is needed for high melting polymers to prepare flame-retardant fibers. A comparison of different spinning methods using poly(lactic acid) (PLA) as a model polymer has been reported by Gupta et al. [41].

The melt of the polymer with other additives is extruded through the capillary, resulting in a thin fiber that cools and solidifies rapidly during its time in the air before depositing onto the collector [41]. Take-up speed, drawing temperature and draw ratio define the structural and tensile properties of the fiber. Draw ratio is the amount of stretching that the material undergoes during the drawing stage of electrospinning. The increase in draw ratio [42] and take-up speed [43] increases the molecular chain orientation along the fiber axis as well as the overall crystallinity of fibers formed from the melt. A higher entanglement of polymer fibers amongst themselves gives sub-par fibers compared to the solution of the same polymer.

The solution spinning method is ideal for polymers or blends of polymers that are thermally unstable or degrade upon melting. Based on how the solvent used for preparing the polymer solution is removed from the fibers, this method can be divided into two different types, namely, dry spinning and wet spinning. The dry spinning process uses hot air or inert gas on the polymer jet to facilitate the solvent's evaporation and fiber solidification. For example, Postema et al. used a solvent combination of chloroform and toluene to produce PLA fibers of high strength by using dry spinning and hot-drawing processes. They were able to obtain an optimal tensile strength of $2.2 \mathrm{GPa}$ by electrospinning at $25^{\circ} \mathrm{C}$ [44]. The wet-spinning process involves the use of a viscous coagulation bath containing the liquid, which is miscible with the spinning solvent but not with the polymer. The interaction between the polymer solvent and non-solvent leads to phase separation and then solvent removal from the jet. 
This process is known to show fiber defects that can, to some extent, be limited by using $3-5 \mathrm{~mm}$ of air gap before the non-solvent, as this allows for stress relaxation of the polymeric chain [41].

In the emulsion electrospinning process, finely ground polymers, insoluble and non-melting, are mixed with another polymer solution with a catalyst and emulsifying agents. The formed emulsion is then electrospun by either the dry or the wet spinning method. This technique has been used in preparing fibers from fluorocarbons with high melting points, ceramics, and polymer blends with flame-retardant properties [45]. Persano et al. have discussed in detail the methods and their industrial application in their review [45].

\subsection{Nozzle Configuration}

Nozzle configuration relates to the number and the arrangement of capillary tubes from which the jets of fibers emerge. A single nozzle configuration is the simplest and most common configuration, wherein the charged solution flows through a single capillary (Figure 1). This particular configuration has been used to electrospin different polymeric fibers either singly [46,47] or in combination [48] or solvent systems [10]. Co-electrospinning of polymer blends in the same solvent or a mixture was the first and most common modification in the process. Zhou et al. mixed polyaniline with poly(ethylene oxide) in chloroform to obtain nanofibers of a size below $30 \mathrm{~nm}$ [49]. Sometimes polymer blends are used to obtain the final properties of fibers. If the polymers are not miscible in a common solvent, or when a homogeneous solution of polymers cannot be obtained, thermodynamic and kinetic aspects should be considered for electrospinning. One way around that problem is to modify the nozzle configuration, where different polymer solutions are electrospun from different capillaries, side-by-side. In this type of configuration, two polymer solutions pass through separate capillaries arranged side-by-side, which are connected to a high voltage supply and never come into contact until they reach the end of the capillary. A single Taylor cone is formed, which ejects the jet with a non-uniform mixture of both polymer solutions and, after drying, is deposited in the collector (Figure 3). The side-by-side technique yields Janus fibers having two different materials on either side of the fiber. The special morphology obtained provides combinational properties of two different polymers and allows several post electrospinning modifications [50]. For this type of configuration to work, it is necessary that both the polymeric solutions have similar conductivity for them to form a single Taylor cone and eject as a mixture. A bicomponent system consisting of poly(vinyl chloride)/segmented polyurethane and poly(vinyl chloride)/poly(vinyl fluoride) was studied [51].

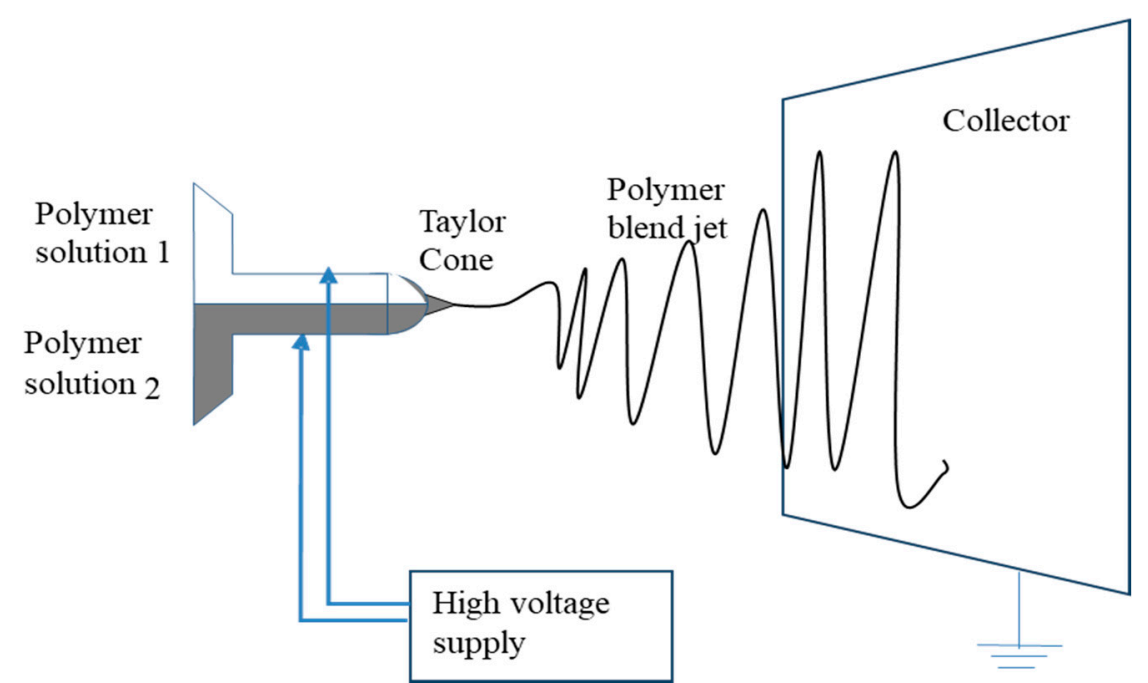

Figure 3. Side-by-side electrospinning schematic diagram: Polymer solutions 1 and 2 pass through separate capillaries, which are connected to the same high voltage supply, at either the same or different rates. A single Taylor cone is formed, which ejects the jet with non-uniform mixture of both the polymer solutions and, after drying, is deposited on the collector. 
A second type of nozzle configuration that has recently been introduced is coaxial configuration. Two separate polymer solutions flow through two different capillaries, where the small capillary is within the larger capillary. This configuration can easily encapsulate a small fiber within a larger fiber, forming core-shell morphology (Figure 4). In one study, living cells were encapsulated in poly(dimethylsiloxane) fiber with high cell viability $(67.6 \pm 1.9 \%)$ compared to the control cells $(70.6 \pm 5.0 \%)$. Though the initial viability was comparable, over time, issues with cell morphology and growth rate were observed. This was the first study of its kind, and authors noted the need for further research to obtain the best possible results for encapsulation of living cells [52]. Encapsulation of a model protein, fluorescein isothiocyanate conjugated bovine serum albumin (BSA), with poly(ethylene glycol) in poly(epsilon-caprolactone), was able to sustain the release of the drug, defining its use in drug delivery. Coaxial fibers of proteins, such as fibrinogen [53], BSA, and lysozyme [54] and growth factors, such as bone morphogenetic protein2 (BMP-2) [55], bFGF [56], PDGF [57], VEGF [58], and EGF [59] have been reported. Apart from the regular parameters that affect the quality of fibers being produced by coaxial electrospinning, the relative flow rate of the core and the shell solutions (ratios between 5:1 and 6:1) is important in determining the encapsulation efficiency [60]. At a lower flow rate, the core phase is not continuous, which results in breaking up of the core, whereas a higher flow rate causes the formation of pendent droplets. Wang and co-workers reported that an optimal flow rate, the core diameter could be easily controlled. Also, the flow rate is related to the core diameter by scaling laws of $d_{f} \sim Q_{c}{ }^{0.18}$ where $d_{f}$ represents the inner diameter of the fiber and $\mathrm{Q}_{\mathrm{c}}$ represents the flow rate of core solution [61] This method is widely used in tissue engineering to achieve sustained, local and efficient gene and growth factor delivery to the cells $[60,62,63]$. Coaxial fibers of different non-steroidal anti-inflammatory drugs such as ketprofen [64], flurbiprofen axetil [65], and ibuprofen [64] and antibiotics such as levofloxacin, tetracycline hydrochloride, ciprofloxacin, moxifloxacin, and fusidic acid [66] were prepared and investigated. Though this method is now widely used, it still has the drawbacks of complexity of design and precise control of spinning parameters e.g., interfacial tension, viscoelasticity of the polymers or two different solutions used.

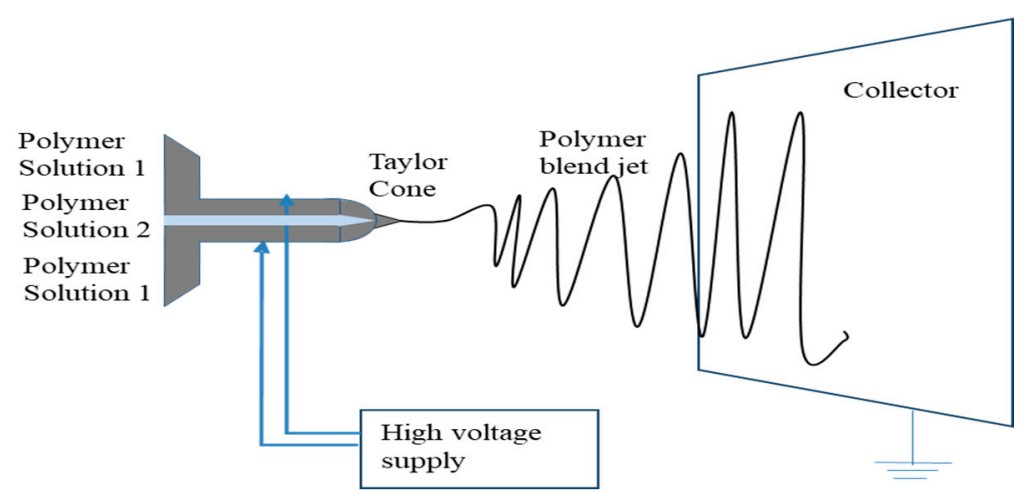

Figure 4. Coaxial electrospinning schematic diagram: Polymer solution 2 is passed through the inner capillary tube, while polymer solution 1 is passed through the outer capillary tube. The Taylor cone is formed where the inner solution (polymer solution 2) is surrounded by the outer solution. The jet erupts from the Taylor cone, and during that process, the polymer in the inner layer is coated with the polymer in the outer layer. The dried fiber with a core-shell design is then deposited on the collector.

The multi-jet electrospinning based on multiple capillaries arranged in circular geometry is yet another modification of the nozzle that can both increase the throughput and facilitate scale up and commercialization. This modification increases the mat thickness, deposits in a larger area and can mix fibers of different materials for better strength and versatility of use $[21,67]$. In the study by Varesano et al., the morphology of PEO fibers was found to be acceptable in both polarities applied in standard and reverse configuration [21]. The main drawback of the multi-capillary method is the alteration of the electric field due to the presence of other electrospinning jets in the vicinity [68]. 
This can be overcome by using an auxiliary electrode of any polarity [69] or by using a secondary electrode [70]. Hong et al. fabricated an elastic, fibrous, composite sheet with biodegradable poly(ester urethane) urea (PEUU) and poly(lactide-co-glycolide) (PLGA) using a two-stream electrospinning setup with a rotating metal rod as the collector [71]. Such composite sheets possessed better breaking strains, tensile strength and suture retention capacity. In a review article, Persano et al. discussed different multi-jet configurations and the further possibilities of syringe-free approaches to multi-jet electrospinning [45].

\subsection{Collector Modification}

The collector plate can be configured based on the application of polymeric fibers. Commercially, the most common collectors are stationary plates (or aluminum foil) and rotating plates. Both these types of collectors can be subdivided further into continual or patterned. A continual collector is simple and can be used to obtain fibers with a random internal structure on a stationary type, while some degree of directional control can be gained with the higher speed of a rotating collector. The patterned collectors have thin conductive wires separated from one another by an air gap. During the process, the fibers are deposited either between or perpendicular to the wires, individually, achieving some degree of alignment. Properly aligned polymer fibers are mostly useful in tissue engineering. In the rotating type of patterned collector, operation at lower speeds deposits fibers between the conductive wires, while deposits at the higher speed are dependent on electrostatic and mechanical forces increasing the degree of alignment. For research purposes, different designs of collectors have been used, including: mesh [72], pin [73], grids [74], liquid bath [75,76], rotating rods [77], rotating cylinder [78], parallel bars [77], rotating drum with wire wound on it [79], and disc [34,80].

\section{Methods of Incorporating Drugs}

Electrospinning is easy and cost effective, and it offers great flexibility in selecting materials, high loading capacity and high encapsulation efficiency, which makes it suitable for medical and drug-related research. There are various methods of drug loading in the polymeric solution for electrospinning.

\subsection{Blending}

Blending is the primary method for incorporating drugs into the polymer solution by dissolving or dispersing the drug and then subsequently electrospinning. Though this method is simple and easy, the physicochemical properties of the drug and the polymer need to be precisely considered, as these affect the encapsulation efficiency, the drug distribution in the fiber and the kinetics of the drug release. Lipophilic drugs (e.g., paclitaxel) should be dissolved in a lipophilic polymer and hydrophilic drugs (e.g., doxorubicin hydrochloride) in a hydrophilic polymer for better encapsulation. When the drug is not dissolved properly in the polymer solution, a dispersion is obtained, which might lead to burst release if the drug migrates to the fiber surface [81]. To obtain a sustained release of the drug from the electrospun fibers, in order to enhance the drug-loading efficiency and to reduce the burst release, different combinations of the mixtures of hydrophilic and hydrophobic polymers are used [82-84]. This process was modified by Ma et al. to obtain highly porous chitosan nanofibers by electrospinning chitosan/polyethylene oxide (PEO) blend solutions and then removing PEO with water [85]. They then soaked the porous nanofibers in $0.1 \mathrm{wt} \%$ paclitaxel solution to load the drug, and then into $4 \mathrm{wt} \%$ hyaluronic acid for encapsulation. Mickova et al. have compared electrospinning of a liposome by blending and by coaxial electrospinning and have reported that blend electrospinning could not conserve intact nanofibers [86].

\subsection{Surface Modification}

Surface modification is the technique in which the therapeutic agent is bound or conjugated to the fiber surface to make it structurally and biochemically similar to the tissue. The drug release in 
this case will be attenuated, and the functionality of the biomolecules will be protected [87]. The burst release and short-term release will be mitigated with this strategy, making it highly applicable for slow and prolonged delivery of gene or growth factors. Incorporation of DNA, growth factors and enzymes, conjugated to fibers, preserves their bioactivity and functionality [87-90]. The modulation of drug release can also be obtained if surface modification is done on blended electrospun fibers. Im et al. fluorinated the electrospun fibers to obtain controlled release of the drug by introducing a hydrophobic group onto the surface [91]. In one modification, Yun et al. oxyfluorinated the multi-walled carbon nanotubes (MWCNTs) to introduce the functional groups and improve the compatibility with the PVA/polyacrylic acid (PAA) polymer solution before electrospinning the composite mixture [92]. Kim et al. surface modified the fiber and loaded it with small-interfering RNA (siRNA) to obtain better results in gene silencing and wound healing [93]. Co-axial electrospinning encapsulates biomolecules like DNA into the fiber, in contrast to surface localization of DNA fibers with the blending process. Luu et al. reported that the transfection efficiency of electrospun DNA was significantly lower than Fugene 6, a commercially available transfection mediation agent [94]. To overcome the drawback, the electrospinning method was changed to coaxial to get a polymer coating around the biomolecules, which not only modified the release, but also protected the core against the direct exposure to the environment $[60,62,95]$. For additional benefits, the shell polymer can also be loaded with other bioactive molecules, such as non-viral gene-delivery vectors, for delivering the released DNA [62].

\subsection{Emulsion}

Another approach is the process of forming an emulsion for electrospinning, where the drug or the protein solution is emulsified within a polymer solution. The latter acts as an oil phase, and spinning such an emulsion produces a well-distributed fiber for a low molecular weight drug [96] and a core-shell for a high molecular weight drug [97-99]. The success of this process is mainly dependent on the ratio of the aqueous solution to the polymer solution. This governs the distribution behavior of the molecule in fiber, which in turn determines the release profile, structural stability and bioactivity of the encapsulated biomolecules [97]. As the drug and the polymers are dissolved in appropriate solvents, avoiding the need of a common solvent, various combinations of hydrophilic drugs and lipophilic polymer can be used. Unlike coaxial spinning, emulsion spinning might damage macromolecules, such as pDNA, due to shearing force and interfacial tension between the two phases. Such instances can be avoided by preventing denaturation by the condensation of pDNA $[98,99]$.

\subsection{Multi-Drug Delivery}

Multi-drug delivery is a recent approach in which multiple drugs with or without similar therapeutic effects are combined and electrospun with suitable polymer(s) [100,101]. Wang et al. have used drug-loaded polymeric nanoparticles for the core and drug-loaded polymer for the sheath to obtain a chain-like structure with a distinct release behavior, enabling a program or temporality release of multiple agents [100]. Xu et al. have developed a hydrophilic model of bovine serum albumin (BSA) drug-loaded chitosan microspheres and suspended them in poly(l-lactic acid) (PLLA) solution with a hydrophobic model drug (benzoin) and polyvinylpyrrolidone (PVP) as a release tuner [101]. It is difficult to achieve independent release of the drugs in a multidrug system, as both drugs are held by the carrier, which provides the same diffusion pathways and matrix-degradation rate [95]. Okuda et al. have developed a multilayered drug-loaded electrospun nanofiber mesh fabricated for time-programmed dual release by sequential electrospinning. The formulation has four layers: the drug-loaded mesh (the top layer), the barrier mesh (blank polymer), the second drug-loaded mesh and the last basement mesh. This system provided for the development of electrospun fibers with controlled drug release and time of release by optimizing the fiber size, thickness of each layer and relative position of the layer. Though the authors have used two dyes as model drugs, this approach is significant for the biochemical modulation in chemotherapy with multiple-anti tumor drugs [102]. A graphical presentation of the same is shown in Figure 5. 


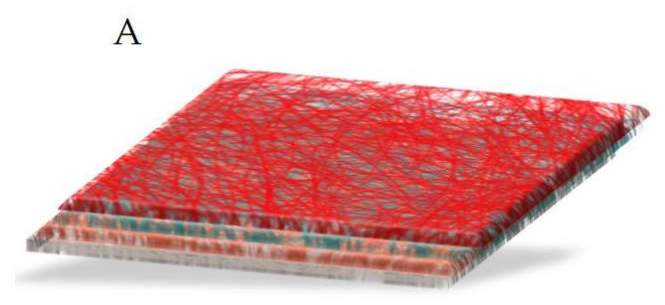

B

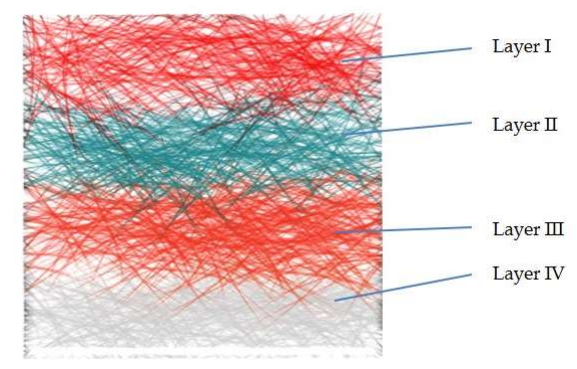

Figure 5. Graphical presentation of multi-drug delivery system: (A) overview; (B) cross sectional view of a tetra-layered sequential electrospun mesh. Cross-sectional view consists of drug loaded mesh (layer I), barrier mesh (layer II), second drug loaded mesh (layer III) and basement mesh (layer IV). Redrawn from [102].

\subsection{Multilayer Coated}

Yet another innovative method of incorporation and delivery of drug combines the large surface area of electrospun fibers with polyelectrolyte multilayer structures [95]. Such a multilayer uses either electrostatic or hydrogen bonding or acid-base pairing in layer-by-layer adsorption of polymers [103]. Chundar et al. have used two oppositely charged weak polyelectrolytes, polyacrylic acid (PAA) and poly allylamine hydrochloride (PAH), to produce nanofibers loaded with methylene blue as a model drug. In addition to polymers, a hydrophobic layer of perfluorosilane and PAA/poly(N-isopropylacrylamide) (PNIPAAM) was coated. The latter also provided temperature-controlled drug-release properties. Im et al. used alginate and chitosan to coat the lactobacillus-incorporated polyvinyl alcohol-based electrospun fibers. This formulation was designed to release lactobacillus in the large intestine after chitosan and alginate were dissolved in the acidic and then neutral environments of the GIT [104].

\section{Electrospun Nanofibers in Drug Delivery}

The electrospinning process has been used in drug delivery for treating various diseases. Electrospun fibers are administered mainly via oral and topical routes and as implantable systems.

\subsection{Vitamins, NSAIDS and Natural Products}

The transdermal drug delivery system (TDDS) delivers the drugs locally or systemically via the skin. This is mainly suitable for drugs that cannot be taken by the oral route, either because of extensive degradation in the GIT or because the drug undergoes extensive first pass metabolism [105]. Electrospun fibers of vitamins, anti-inflammatory and antioxidant drugs are mainly given by transdermal route [92,106-111]. Taepaiboon et al. have loaded vitamin A acid (all-trans retinoic acid) and vitamin E ( $\alpha$-tocopherol) in cellulose acetate polymer-based electrospun fibers and solvent cast films [110]. The results obtained revealed that the electrospun fiber mats showed a gradual and consistent increase in the cumulative vitamin release assayed using a total immersion technique over the test period of $24 \mathrm{~h}$ for vitamin E- and $6 \mathrm{~h}$ for vitamin A-loaded fiber. The corresponding solvent cast films showed a burst release of vitamins. A similar study performed by Nagwhirunpat et al. compared the electrospun and solvent cast film of polyvinyl alcohol loaded with meloxicam, an anti-arthritis drug [111]. They observed significantly higher skin permeation flux of the drug from electrospun fiber mats than with the solvent cast film, and the flux increased with an increase in drug concentration in both cases. Yun et al. developed an electro-responsive TDDS fiber by electrospinning poly(vinyl alcohol)/poly(acrylic acid)/multi-walled carbon nanotubes (PVA/PAA/MWCNT) with ketoprofen. The swelling, drug-release properties and conductivity of nanofibers were dependent upon the MWCNT, oxyfluorination and oxygen content during oxyfluorination [92]. The fibers were found to be non-toxic and biocompatible, with cell viability of more than $80 \%$. In a similar study, Im et al. worked to understand the effect of MWCNT on ketoprofen delivery in an electro-sensitive 
TDDS with polyethylene oxide and pentaerythritol triacrylate polymers [109]. This study supported the impact of MWCNT in influencing conductivity and drug-release behavior. Reda et al. formulated ketoprofen-loaded Eudragit ${ }^{\circledR} \mathrm{L}$ and Eudragit ${ }^{\circledR} \mathrm{S}$ electrospun nanofibers for treating oral mucositis. The rapid evaporation of solvent during electrospinning prevented the drug molecules from forming crystalline aggregates within the nanofibers. In addition, the amount of ketoprofen released from nanofibers was significantly higher than that released from corresponding solvent-casted films. Furthermore, a marked reduction in inflammatory infiltrate was seen in mucositis-induced rabbits with developed nanofibers [112]. Apart from the synthetic chemicals, a natural/herbal extract containing asiaticoside from Centella asiatica was incorporated into the electrospun fibers based on cellulose acetate polymer [106]. Suwantong et al. used two forms of the drug, pure asiaticoside and a crude extract from the plant. They observed a better release profile from the pure drug than from the extract assayed using the immersion method, while the release from both fiber mats was significantly low in the pigskin method. In addition, they checked the release profile of the solvent cast films, which were much lower. They further reported that the extract-loaded fibers and films were toxic to normal human dermal fibroblasts at the extraction concentrations of 5 and $10 \mathrm{mg} / \mathrm{mL}$ [106].

\subsection{Antibiotics/Antibacterial Agents and Wound Dressing}

In recent years, antibiotics and antibacterial agents have been the most common drug molecules that are encapsulated, using different polymers and their combinations as carriers. Different polymers, such as PLA, PLGA and PCL, are primarily used in the polymeric electrospun fibers for biodegradability, and other natural and synesthetic hydrophilic or hydrophobic polymers are used to control the release pattern of the drug. Kenaway et al. used tetracycline hydrochloride with poly(ethylene-co-vinyl acetate) (PEVA), PLA and their 50:50 blend to deliver the drug for treating periodontal disease [113]. They reported over five days of release with PEVA and the blend, suggesting their applicability in controlled-release technology. In another study by Alhusein et al., electrospun fibers of tetracycline $\mathrm{HCl}$ using PCL and PEVA were developed for potential application in wound healing and skin-structure infections. The developed three-layered electrospun matrix showed controlled release and also higher antibacterial efficacy when compared to the commercially available test disks of the drug [114]. The same group of researchers also reported high biological activity of the developed fiber matrices in complex models of biofilm formation. The fibers killed preformed biofilms and mature dense colonies of Staphylococcus aureus MRSA252 and also inhibited the formation of new biofilms [115]. Wang et al. have electrospun PVA nanofibers containing pleurocidin, a novel, broad-spectrum antimicrobial peptide, for food preservation applications [116]. Direct application of the active moiety is not possible because of the loss in its bioactivity. This study reported higher inhibition efficacy of the drug from nanofibers against Escherichia coli in apple cider.

Wound dressings protect the wound from external microorganisms and absorb/adsorb the exudate from the wound, providing an acceptable cosmetic appearance. The use of different components in the wound dressing prevents infection of the wound and accelerates the healing process [117]. The components added to the inert dressings are mainly bioactives in the form of films, hydrogels, foams and sponges [84]. With respect to wound healing, electrospun fiber mats have the advantage of high surface area for efficient absorption of exudates; in addition to adjusting the moisture of the wound and promoting scar-free regeneration of skin cells, these mats have porosity enough to supply oxygen for cell respiration, yet not enough for bacterial infections $[58,117,118]$. In one study by Jannesari et al., electrospun nanofibers of poly(vinyl alcohol) and poly(vinyl acetate) were prepared individually and in a 50:50 blend of the polymers. The nanofibers prepared using the polymer blend sustained the drug release and were found to be comfortable due to significant swelling [84]. In an in vitro microbial study, Said et al. have shown a faster bacterial colonization and biofilm formation in fusidic acid-loaded PLGA fibers, which in turn enhanced the release of the drug, eradicated planktonic bacteria and suppressed the biofilm [119]. Thakur et al. used the dual spinneret electrospinning apparatus to prepare a single scaffold of lidocaine and mupirocin [120]. Two drugs 
with varying lipophilicities were found to have different release profiles. Lidocaine showed a burst release, while mupirocin showed sustained release, providing action for over $72 \mathrm{~h}$. Wang et al. have fabricated nanofibers of ethylene-co-vinyl alcohol (EVOH) with different antibacterial drugs and silver for wound dressings with superior germ killing capacity [121]. Silver nanoparticles have been used in many other studies for similar applications [66,122]. Recently, Chutipakdeevong et al. have utilized the hybridization method to combine the properties of Bombyx mori silk fibroin with poly( $\varepsilon$-caprolactone) (PCL) electrospun fibers [123]. The PCL fiber surfaces were coated with silk fibroin protein using the lyophilization technique and then surface modified with fibronectin to improve their biological function. The surface-modified hybrid showed significant proliferation of normal human dermal fibroblast (NHDF), followed by hybrid scaffold and then neat PCL fibers.

\subsection{Delivery of Anticancer Agents}

Anticancer agents, such as doxorubicin, paclitaxel, cisplatin and dichloroacetate, have been incorporated into electrospun fibers with polymers such as PLA, PLGA and PLLA for postoperative chemotherapy. A water-in-oil $(w / o)$ emulsion, with water soluble drugs in aqueous phase and polymeric solutions of PEG-PLA in chloroform as oily phase, was prepared and electrospun to obtain fibers [124]. In a continuation study, hydrophobic paclitaxel and hydrophilic doxorubicin were simultaneously loaded in the emulsion based electrospinning process for multi-drug delivery [125]. The cytotoxicity study of rat Glioma C6 cells showed higher inhibition and apoptosis in combination therapy compared to the single-drug system. In another study, an in vitro cytotoxicity study of the same cells showed a sustained release of platinum-based cisplatin for more than 75 days without burst release and four times better cytotoxicity than the free drug [126]. Lee et al. have fabricated biodegradable PLGA fibers sheets for local delivery of epigallocatechin-3-O-gallate (EGCG) to reduce intimal hyperplasia in injured abdominal aorta [116]. The EGCG-loaded sheets exhibited initial burst release for $24 \mathrm{~h}$, followed by sustained release for more than 30 days in phosphate buffer. In vivo studies showed promising results against intimal hyperplasia after application of the EGCG-loaded fibers, compared to PLGA control.

Recently, electrospun fibers have been used for local chemotherapy. Liu et al. encapsulated doxorubicin in PLLA polymer fiber and examined its efficacy for local chemotherapy against secondary hepatic carcinoma by wrapping the whole liver with carcinoma with the fiber-mat [127]. In the first $24 \mathrm{~h}$, the drug was rapidly released from the fiber to localize in the liver tissue. It also significantly inhibited the tumor growth and increased the median survival time of the mice in the experiment. Luo et al. prepared fibers with core-loaded hydroxycamptothecin (HCPT) and 2-hydroxypropyl- $\beta$-cyclodextrin complexed HCPT, and observed that the inclusion complex showed superior antitumor activity and fewer side effects compared to the free drug [128]. Ma et al. loaded paclitaxel in the porous chitosan nanofiber and then encapsulated the fiber in polyanionic macromolecular hyaluronic acid (HA). The MTT assay in prostate cancer cells showed that the drug-loaded nanofiber mats were good at prohibiting cell attachment and proliferation [129]. The drawback of the fibers was an initial burst release of drug within the first $48 \mathrm{~h}$. Chen et al. incorporated titanocene dichloride in PLLA polymer-based fibers [130]. The MTT assay in human lung tumor (SPCA-1) cells showed that drug contents of $40,80,160$ and $240 \mathrm{mg} / \mathrm{L}$ had cell growth inhibition rates of $11.2 \%, 22.1 \%$, $44.2 \%$ and $68.2 \%$, respectively. Apart from the synthetic anticancer drug, natural products with anticancer properties and minimal side effects have been studied. Suwantong et al. electrospun curcumin in cellulose acetate solution and observed that curcumin is almost completely ( $\sim 90$ to $~ 95 \%$ ) released in the total immersion method, while considerably low values were obtained for transdermal diffusion through pig skin [108]. In another study, Shao et al. fabricated green tea polyphenols (GTP) in poly (E-caprolactone)/multi-walled carbon nanotube (PCL/MWCNTs) composite nanofibers by electrospinning. The cytotoxicity experiment showed a significant inhibitory effect in A549 and Hep G2 tumor cells [131]. Table 1 provides a compilation of studies involving the use of electrospun fibers in delivering antibiotics, anticancer agents and NSAIDS. 
Table 1. Studies involving the use of electrospun fibers in drug delivery (partial listing).

\begin{tabular}{|c|c|c|c|}
\hline Drug(s) & Polymer(s) & Solvent Composition & Spraying Type \\
\hline \multicolumn{4}{|c|}{ Antibacterial agents } \\
\hline Tetracycline hydrochloride & $\begin{array}{l}\text { PEUU and PLGA [71]; PLA, PEV, PLA/PEVA } \\
\text { [113]; PLA/PCL [132] } \\
\text { PLLA [133,134]; PCL, PEVA [114] }\end{array}$ & $\begin{array}{l}\text { 1,1,1,3,3,3-Hexafluoro-2-propanol [71]; } \\
\text { Chloroform [113]; Chloroform, } \\
\text { dimethylformamide [132]; } \\
\text { Chloroform: acetone (2:1) [133,134]; } \\
\text { chloroform:methanol (9:1) [114] }\end{array}$ & Single nozzle; Coaxial $[133,134]$ \\
\hline $\begin{array}{l}\text { Gentamycin sulfate and } \\
\text { Resveratrol (antioxidant) }\end{array}$ & PCL [133] & Chloroform: ethanol (3:1) & Coaxial \\
\hline Ciprofloxacin Hydrochloride & PVA, Poly(vinyl acetate) [84] & Diluted acetic acid solution & Single nozzle \\
\hline Fusidic acid and rifampicin & PLGA [135] & Tetrahydro Furan/Dimethylformamide & Single nozzle \\
\hline Mefoxin & PLGA [83] & DMF & Single nozzle \\
\hline Metronidazole benzoate & PCL [136] & Dichloromethane (DCM:DMF) & Single nozzle \\
\hline $\begin{array}{l}\text { Ciprofloxacin hydrochloride, } \\
\text { Levofloxacin hemihydrate, } \\
\text { Moxifloxacin hydrochloride }\end{array}$ & coPLA, coPLA/PEG [137] & DCM:DMSO (3:1) & Single nozzle \\
\hline Lidocaine and mupirocin & PLLA [120] & Hexafluoroisopropanol & Dual spinneret \\
\hline Ornidazole (Biteral ${ }^{\circledR}$ ) & PCL & Chloroform and DMF (3:7) & Single nozzle \\
\hline Potassium 5-nitro-8-quinolinolate & Chitosan/PEO [138] & $2 \%(w / v)$ acetic acid & Single nozzle \\
\hline Itraconazole and ketanserin & PU [139] & DMF, DMAc & Single nozzle \\
\hline Pleurocidin & PVA [116] & Distilled water & Single nozzle \\
\hline \multicolumn{4}{|c|}{ NSAIDS } \\
\hline Ketoprofen & $\begin{array}{l}\text { PVA/PAA/MWCNT [92]; } \\
\text { PEO/PETA/MWCNT [109]; EC and PVP } \\
\text { [140]; PVP/Zein [141] }\end{array}$ & $\begin{array}{l}\text { Deionized water }[92,109] \\
\text { Ethanol-water }[140,141]\end{array}$ & $\begin{array}{l}\text { Single nozzle } \\
\text { Coaxial [141] }\end{array}$ \\
\hline Ibuprofen & PLGA PEG-g-CHN [142] & DMF & Side-by-side \\
\hline Fenbufen & PLGA/Gelatin [82] & 2,2,2-trifluoroethanol & Single nozzle \\
\hline Rhodamine B/Naproxen & Chitosan nanoparticles/PCL composite [100] & Acetic acid/chloroform: methanol (3:1) & Single nozzle yet core/sheath fiber \\
\hline Meloxicam & PVA [111] & Water & Single nozzle \\
\hline
\end{tabular}


Table 1. Cont.

\begin{tabular}{llll}
\hline \multicolumn{1}{c}{ Drug(s) } & \multicolumn{1}{c}{ Polymer(s) } & \multicolumn{1}{c}{ Solvent Composition } \\
\hline $\begin{array}{l}\text { Doxorubicin [127] } \\
\text { Doxorubicin Hydrochloride }\end{array}$ & $\begin{array}{l}\text { PLLA [127] } \\
\text { PEG-PLA [124,143] }\end{array}$ & $\begin{array}{l}\text { Chloroform-methano-DMSO [127] } \\
\text { Chloroform [143] } \\
\text { w/o emulsion [124] }\end{array}$ & $\begin{array}{l}\text { Single nozzle } \\
\text { Emulsion [124] }\end{array}$ \\
\hline Hydroxycamptothecin & HPCD [128] & DMSO & Emulsion \\
\hline Paclitaxel & Chitosan/PEO/HA [84] & Acetic acid/distilled water [84] & Single nozzle \\
\hline Cisplatin & PLGA [144,145] & DCM and DMF & Single nozzle \\
\hline Dichloroacetate & PLA/PLGA [126] & DCM & Single nozzle \\
\hline 1,3-Bis(2-chloroethyl)-1-nitrosourea & PEO and PEG-PLLA [147] & Chloroform & Single nozzle/Emulsion \\
\hline Curcumin & Cellulose acetate [108] & Chloroform & Single nozzle \\
\hline Green tea polyphenols (GTP) & PCL/MWCNT [131] & Acetone/dimethylacetamide (2:1) & Single nozzle \\
\hline Titanocene dichloride & PLLA [130] & Dichloromethane & Dichloromethane \\
\hline
\end{tabular}

PLA: Poly(lactic acid); PEVA-Poly(ethylene-co-vinylacetate); PCL: poly(e-caprolactone); PCL-co-PCLEEP: Copolymer of caprolactone and ethyl ethylene phosphate; PLGA: Poly(D,L-Lactic acid-co-glycolic acid); PEUU: poly(ester urethane) urea; EC: ethyl cellulose; PEO: Poly(ethylene oxide); PU: Polyurethane; DMAc: Dimethylacetamide; PETA: pentaerythritol triacrylate; PEI-HA: Poly(ethylenimine)-hyaluronic acid; PVP: polyvinylpyrrolidone; PEG-g-CHN: poly(ethylene glycol)-g-Chitosan; PEG-PLA: poly(ethylene glycol)-poly(lactic acid); PLLA: poly(L-lactic acid); HPCD: 2-hydroxypropyl- $\beta$-cyclodextrin; HA: Hyaluronic acid; MWCNT: multi-walled carbon nanotubes, PAA-Poly(acrylic acid); PECCL: poly(ethylene carbonate- $\varepsilon$-caprolactone); PDLLA: poly(D,L-lactic acid). 


\subsection{DNA, RNA, Protein and Growth Factor Delivery}

The most commonly loaded bioactive materials in electrospun fibers include DNA, RNA, proteins and growth factors. The electrospinning process applied to the bioactive materials should be designed in such a way that the activity and functional efficacy of the material is preserved during and after electrospinning. Before coaxial electrospinning, few studies on bioactive materials had been done with the blending process. The stability of the growth factors is the limiting aspect in formulating them in tissue-engineered scaffolds. Human nerve growth factor (hNGF) was encapsulated with BSA as a carrier protein into the nanofibers of PCL and poly(ethyl ethylene phosphate) (PCLEEP). The protein released in a sustained manner for more than three months from the electrospun fibers and showed partial retention of bioactivity [148]. The same group also co-encapsulated small-interfering RNA (siRNA) and transfection reagent (TKO) complexes within a nanofiber of caprolactone and ethyl ethylene phosphate (PCLEEP, diameter $\sim 400 \mathrm{~nm}$ ) to obtain a sustained release of siRNA for up to 28 days [149]. The release of siRNA was enhanced and more significant gene knockdown was obtained when compared with electrospun fibers of PCL containing siRNA [150]. Schneider et al. demonstrated that biofunctionalized silk mats containing epidermal growth factor (EGF) are extremely promising in achieving bioactive wound dressings for the wound healing process [151]. Similarly, Zhang et al. showed that the poly(ethylene carbonate- $\varepsilon$-caprolactone) scaffolds with VEGF maintained good growth and spread morphology in human umbilical vein endothelial cells [152]. After the introduction of the coaxial electrospinning method, most biomolecules are preferentially encapsulated using this method, forming a core of biomolecule and shell of polymer in a core-shell structure. The polymeric shell protected and released biomolecules in a sustained manner. Saraf et al. prepared fiber scaffolds with plasmid DNA (pDNA) within the core of poly(ethylene glycol) and non-viral gene delivery vector poly(ethylenimine)-hyaluronic acid (PEI-HA) within the sheath polymer poly( $\varepsilon$-caprolactone) (PCL) by coaxial electrospinning [62]. They achieved variable transfection activity over extended periods of time upon the release of pDNA and non-viral gene delivery vectors from electrospun fiber scaffolds. Mickova et al. have proposed the use of liposomes in the core of polyvinyl alcohol (PVA) and shell of PCL for protecting the enzymatic activity of horseradish peroxidase [86]. The encapsulated enzyme retained its activity because of the shielding effect of the lipid sphere of liposome. Chen et al. encapsulated chitosan/siRNA nanoparticles in PLGA by electrospinning to control the release behavior at different $\mathrm{pH}$ conditions. In addition, the encapsulated siRNA showed up to $50 \%$ enhanced green fluorescent protein (EGFP) gene silencing activity after $48 \mathrm{~h}$ of transfection in H1299 cells [143]. Surface functionalization of nanofibers was performed for MMP-2-siRNA (Matrix metalloproteinase) in linear polyethyleneimine (LPEI) coated nanofibers with various nitrogen/phosphate (N/P) ratios [93]. In an animal study for seven days, it was observed that the siRNA in these fibers increased the MMP-2 gene silencing effect and neo-collagen accumulation at the wound site. Fabrication of surface modified electrospun fibers containing growth factors conjugated with heparin or polysaccharides is becoming common $[87,89,153]$. A burst release of nerve growth factor was observed from electrospun scaffolds conjugated with chitosan/poly(vinyl alcohol) [89]. Basic fibroblast growth factor was incorporated in heparin containing a polyelectrolyte nanoparticle, and that was electrostatically adsorbed on the chitosan matrix to overcome the problem of burst release [87]. Han et al. fabricated a composite design containing poly(ethylene glycol)-poly-( $\varepsilon$-caprolactone) diacrylate (PEGPCL) hydrogels coupled with electrospun mats of poly( $\varepsilon$-caprolactone) to control the burst release and to extend the release duration of nerve growth factor [154]. The bioactivity of the growth factor was demonstrated by PC-12 cells' neurite extension. Further, immobilization and delivery of the growth factor for the bone tissue engineering is discussed in the review by Chen and Lv [155]. In addition, electrospinning has extensively been used and reviewed for tissue scaffold engineering with or without any active moiety incorporated in the polymeric matrix. Table 2 provides a list of studies involving the use of electrospun fibers in delivering proteins, DNA, RNA and human factors. 


\subsection{Nanoparticle Impregnated Nanofibers}

Electrospun nanofibers containing nanoparticles is another area of research that has been widely investigated for various applications, including surface-enhanced Raman scattering [156], antimicrobial packaging [157], dye-sensitized solar cells [158], food preservation [159], biowarfare decontamination [160], water treatment [161], high-performance gas sensing [162], and environmental remediation [163]. In drug delivery, these novel impregnated nanofibers are being explored in the areas of wound care, regenerative medicine, dental engineering, and for cancer treatment. In this section, we briefly summarized biomedical applications of nanoparticle impregnated nanofibers.

A study conducted by Lee et al. investigated the efficacy of chitosan (CTS) nanofibers containing silver nanoparticles for topical wound care. Silver nanoparticles were generated directly in the chitosan solution by chemical reduction using sodium borohydride. The nanoparticle solution obtained was then poured into sodium hydroxide resulting in the formation of CTS/AgNPs composite, which was further subjected to electrospinning to form nanofibers. The prepared fibers showed excellent antibacterial activity against $P$. aeruginosa and methicillin-resistant $S$. aureus when compared to the pure CTS nanofibers [164]. Similarly, Shi et al. prepared Ag/polyacrylonitrile (Ag/PAN) anti-bacterial nanofibers for use in implant scaffolds and biotextiles. Initially, PAN was dissolved in DMF and a known amount of $\mathrm{AgNO}_{3}$ was added to form the pre-electrospinning solution. The solution was then treated using helium atmospheric plasma to reduce $\mathrm{AgNO}_{3}$ into metallic silver nanoparticles. Finally, the solution obtained was electrospun to form nanofibers containing embedded Ag nanoparticles. SEM images revealed the smooth and continuous nature of the nanofibers. The nanofibers demonstrated a sustained release of silver ions and also showed higher antibacterial activity against Gram positive (B. cereus) and Gram negative bacteria (E. coli) when compared to the untreated nanofibers [165]. Another study conducted by Castro-Mayorga et al., investigated the antiviral properties of Ag nanoparticles in coated polyhydroxyalkonates. The films of poly(3-hydroxybutyrate-co-3-hydroxyvalerate) (PHBV) were developed by depositing a coat of electrospun fiber mat containing post-processed PHBV18/Ag nanoparticles over PHBV3 films formed by compression molding. Energy dispersive X-ray (EDX) analysis showed that Ag nanoparticles were homogeneously distributed into the coating and on the PHBV3/PHBV18 film. Moreover, cell culture analysis revealed no infectious feline calicivirus (FCV) recovery when treated with the prepared films, while murine norovirus (MNV) was decreased by $0.86 \log$ [166].

Nie and Wang studied the complex of DNA and poly lactide-co-glycolide (PLGA)/hydroxyapatite (HAp) composite scaffolds fabricated by electrospinning for their use in bone tissue engineering. DNA was incorporated into the scaffolds in the form of naked DNA or DNA/chitosan nanoparticles before/after fiber fabrication. The results revealed that the scaffolds were non-woven and predominantly composed of PLGA with a dispersion of HAp nanoparticles. The addition of HAp nanoparticles showed an increase in the release rate of DNA from the scaffolds containing both naked and encapsulated DNA. Moreover, the scaffolds with encapsulated DNA/chitosan nanoparticles also showed a higher cell attachment, greater cell viability and desired transfection efficiency in human marrow stem cells (hMSCs) [167]. A similar study conducted by Tanaka and co-workers fabricated hydroxyapatite/PLA composite electrospun nanofibers for bone tissue engineering. The surface-modified HAp nanoparticles of stearic acid were dispersed uniformly in the PLA nanofibers and were evaluated for their mechanical strength. The authors concluded that the electrospun fibers showed higher strength when compared to the unmodified ones [168]. Table 3 provides a partial listing of studies involving the use of electrospun fibers in tissue engineering. 
Table 2. Studies involving the use of electrospun fibers in delivery of proteins, DNA, RNA and human factors (partial listing).

\begin{tabular}{|c|c|c|c|}
\hline Drug(s) & Polymer(s) & Solvent Composition & Spraying Type \\
\hline plasmid DNA (pDNA) & PEI-HA [62] & & Coaxial \\
\hline siRNA & $\begin{array}{l}\text { PCL [150]; PCLEEP [149] } \\
\text { Chitosan/PLGA [169] }\end{array}$ & $\begin{array}{l}\text { 2,2,2-Trifluoroethanol (TFE) [150]; } \\
\text { RNase-free water [149]; } \\
\text { Hexafluoro-2-isopropanol/water [169] }\end{array}$ & Single nozzle \\
\hline Human glial cell-derived neurotrophic factor & PCL-Co-PCLEEP [170] & Dichloromethane & Single nozzle \\
\hline Human $\beta$-nerve growth factor & PCL-Co-PCLEEP [148] & Dichloromethane & Single nozzle \\
\hline Endothelial growth factor VEGF & PECCL [152] & - & Single nozzle \\
\hline Bovine Serum Albumin (BSA) & PEO [171] & Deionized water & Single nozzle \\
\hline Lysozyme & PLA [97] & Chloroform & Emulsion \\
\hline Human-nerve growth factor (NGF) & Poly(L-lactide-co-caprolactone) [172] & Chloroform & Emulsion \\
\hline DNA & PLA-PEG and PLGA [94] & DMF & Single nozzle \\
\hline Growth factors (VEGF, PDGF) & Poly(urethane) [63] & Chloroform: ethanol (75:25) & Coaxial \\
\hline Horseradish peroxidase & PVA/PCL [86] & - & Coaxial \\
\hline
\end{tabular}

Table 3. Studies involving the use of electrospun fibers in tissue engineering (partial listing).

\begin{tabular}{lll}
\hline Drug(s) & Polymer(s) & Solvent Composition \\
\hline Wound healing, tissue engineering, hemostatic agent & Collagen-PEO [173,174] & Hydrochloric acid \\
Adenovirus with gene for green fluorescent protein & Poly(E-caprolactone) [60] & Chloroform: ethanol (75:25) \\
Guided tissue regeneration & PDLLA/PLGA [175] & Chloroform:DMF (9:1) and THF/DMF (3:1) \\
\hline
\end{tabular}


Liposome-enriched nanofibers were investigated for delivering and preserving horseradish peroxidase (HRP) enzymatic activity. Liposomes were prepared using soybean derived L- $\alpha$ phosphatidylcholine encapsulating horseradish peroxidase (HRP) by the extrusion technique. This study compared the activity of HRP in nanofibers developed by coaxial or blend electrospinning with and without liposomes. Blend nanofibers were prepared by electrospinning unilamellar liposomes dispersed in an aqueous solution of PVA and nanofibers, while the coaxial nanofibers were developed using PVA-core/PCL-shell with embedded liposomes. The results indicate that the blending of liposomes could not conserve the intact liposomes, while the nanofibers obtained by coaxial electrospinning retained liposomes. In addition, the core/shell nanofibers not only preserved the activity of encapsulated HRP enzyme but also enhanced the proliferation of mesenchymal stem cells (MSC) [86].

Poly (L-lactic acid-co- $\varepsilon$-caprolactone) (PLACL) nanofibers containing magnesium oxide (MgO) nanoparticles in synergy with aloe vera (AV), curcumin (CUR) and $\beta$-cyclodextrin $(\beta-C D)$ were prepared and evaluated for treating breast cancer. In vitro toxicity of electrospun nanofibers composed of PLACL; PLACL with AV; PLACL with AV and MgO; PLACL with AV, MgO and CUR; and PLACL with $\mathrm{AV}, \mathrm{MgO}$, and $\beta-\mathrm{CD}$ was assessed in MCF-7 cells using the MTT assay. The results showed that PLACL nanofibers containing CUR showed the greatest cell death among all other nanofibrous scaffolds. However, PLACL nanofibers without $\mathrm{MgO}$ nanoparticles exhibited greatest tensile strength [176]. Sperm-shaped microrobots were studied for targeting breast cancer cells in vitro using fabricated nanoparticles. The microrobots were fabricated using electrospinning by a solution composed of polystyrene, dimethylformamide and nanoparticles of iron oxide. Under the influence of an oscillating magnetic field, the robotic sperm could controllably take S-shaped, U-shaped, square paths and selectively target the MCF-7 cells. Moreover, the cell membrane was not damaged after penetration of the robotic sperm into the cancerous cells [177].

Electrospun nanofibers composed of poly ( $\varepsilon$-caprolactone) (PCL) and zero valent zinc nanoparticles were investigated by Sezer et al. to promote neuroglial cell proliferation. Chemical characterization studies indicated that the nanoparticles did not interact chemically with the PCL matrix. In addition, the nanofibers enhanced the tensile strength of the PCL matrix and promoted cell proliferation depending on the amount of zinc nanoparticles embedded inside the PCL matrix [178]. Another study investigated the efficiency of electrospun hybrid scaffolds composed of cyclosporine-loaded PLGA nanoparticles embedded in PCL scaffolds for promoting innervation of bioengineered teeth. The results from histological studies showed that the implantation of designed scaffolds in adult ICR mice did not alter the development of teeth. In addition, the transmission electron microscopy (TEM) and indirect immunofluorescence studies showed that $88 \%$ of the teeth were innervated upon treating with designed hybrid scaffolds [179].

\section{Commercialization Challenges of Electrospinning}

Although the benefits of electrospinning have been largely demonstrated in various fields of science, there is still a great need to implement the production in an efficient way. Several challenges relating to the electrospinning process are yet to be addressed. These include: (a) large-scale manufacturing; (b) accuracy and reproducibility during all the fabrication steps; and, (c) safety and environmental aspects of electrospinning [45]. The major challenges involved in mass production of electrospun fibers include low output per spinneret, clogging of the spinneret tip, inter-jet interference, recovery of vaporized solvents involved in the process, and fiber alignment over a large area of substantial thickness. To produce electrospun nanofibers without any morphology defects, the solution concentration is kept to a minimum, with solvent making up more than $70 \%$ of the solution mass. Therefore, only a fraction of the solution passing through the spinneret actually contributes to the mass of the nanofiber produced [180]. Also, there is a limit on the feed-rate per nozzle and higher rates might result in dripping of the solution from the nozzle, especially if the nozzle is placed in the middle. This is due to the insufficient electric field experienced by the nozzles, which results in inadequate drawing of the solution. 
Clogging of the spinneret due to the solution gelation is highly disruptive and causes production losses. This problem is more apparent with solutions of higher concentration, as they are more viscous [181] and with polymers of high degree of crystallinity [182]. In addition, a solvent with low boiling point also causes clogging of the spinneret tip [183]. While the productivity of the microfiber spinning process can be increased by placing many spinnerets per spinning head, this is not feasible in the case of electrospinning. In electrospinning, the ejected solution spreads out to form an expanding cone and it interferes with the neighboring jets if the spinnerets are packed too close to each other [68]. Uniformity in the fiber layer thickness deposited onto substrate material is also comprised by the inter-jet interference [180].

Another important concern is regarding the solvent used in the electrospinning process. This particular issue is highly important not only for safety reasons during fabrication, but also for the final products, as solvent residues might be trapped inside the electrospun nanofibers. Accurate control over solvent residues becomes crucial in the case of large-volume, solvent-based electrospinning for biomedical and pharmaceutical applications [45]. However, the use of solvent-free spinning should eliminate the risk of solvent residues and recovery of solvents [184]. Due to the lack of reliable and affordable electrospinning technologies, the use of many different active polymeric materials for the fabrication of nanofibers is still limited [45]. In tissue engineering, the other main challenges that impede the progress of electrospinning applications are increasing scaffold thickness and pore size. Moreover, it is highly difficult to produce identical scaffolds, especially between research groups, which narrows the use of electrospun fiber mats for tissue engineering applications. Also, with tailored electrospun fibers, it is challenging to ensure uniformity of the fibers with specific morphologies and properties [185].

The recent development of needleless electrospinning offers the possibility for fabricating electrospun nanofibers on a large scale and addresses the issue of clogging at the spinnerets [186]. Needleless electrospinning systems using rotating disks [187], rollers [188], balls [189], and bubbles [190] that produce huge amounts of nanofibers have been reported by a few researchers. This method involves the formation of numerous small droplets on the drum surface or disk/coil. Moreover, this method does not require the maintenance of Taylor cones throughout the process making it highly advantageous over conventional needle-based method. Nonetheless, this process consumes a lot of energy in order to maintain the high voltage required and thus increases the chance of spark generation in the system. Therefore, solvents with low flash points, such as chloroform, tetrahydrofuran (THF), and toluene cannot be used for needless electrospinning [182]. Another area where considerable progress has been made in recent years is the development of smart electrospun nanofibers. These nanofibers respond to various kinds of stimuli, including $\mathrm{pH}$, ionic strength, temperature, light, electricity, and magnetic field, and undergo physical and/or chemical changes. Studies involving smart electrospun nanofibers, their advantages and shortcomings are detailed in recent review by Weng and Xie [191].

\section{Conclusions}

The electrospinning process has generated a lot of interest in various medical applications due to its ease of use, adaptability and flexibility in controlling the fiber diameter from the micrometer down to the nanometer range. Though this method has been in use for a few decades now, the techniques and the equipment used in the electrospinning process are ever-evolving. Electrospinning began with a single nozzle configuration and evolved into multi-nozzle configurations through coaxial and emulsion spinning configurations. Further studies are being carried out to modify the nozzle configuration and collector design in order to significantly improve fiber properties and simplify the manufacturing process. This review summarizes several key aspects of electrospinning in the use of electrospun fibers in drug delivery with a special emphasis on electrospun nanofibers impregnated with nanoparticles. Studies involving biomedical applications of electrospun nanofibers are also discussed. By careful selection of polymers, it is now possible to deliver various antibacterial agents and anticancer drugs in a required manner using electrospun nanofibers. In order to make further 
progress, particularly in the field of drug delivery, it is necessary to identify ways that allow large-scale fabrication of nanofibers with desired morphological and mechanical properties in a reproducible manner. Despite the relentless efforts being made by academic and industrial scientists, much of the research conducted with electrospun fibers is in vitro. Further progress in the field of electrospun nanofibers will require continued assessment in vivo. Scientists working in this field have to identify ways to use nanofibers for immunotherapy, gene therapy and regenerative medicine in order to meet the current, as well as any future, demands in drug delivery.

Funding: This work was partially supported by the grant from the deArce Memorial Endowment Fund from The University of Toledo.

Conflicts of Interest: The authors declare no conflict of interest. The funders had no role in the writing of the manuscript.

\section{References}

1. Nayak, R.; Padhye, R.; Kyratzis, I.L.; Truong, Y.; Arnold, L. Recent advances in nanofibre fabrication techniques. Text. Res. J. 2011. [CrossRef]

2. Greiner, A.; Wendorff, J.H. Electrospinning: A fascinating method for the preparation of ultrathin fibers. Angew. Chem. Int. Ed. 2007, 46, 5670-5703. [CrossRef] [PubMed]

3. Reneker, D.H.; Yarin, A.L. Electrospinning jets and polymer nanofibers. Polymer 2008, 49, 2387-2425. [CrossRef]

4. Kiyohiko, H. Process for Manufacturing Artificial Silk and Other Filaments by Applying Electric Current. U.S. Patents No. US1699615A, 22 January 1929.

5. Huang, Z.-M.; Zhang, Y.-Z.; Kotaki, M.; Ramakrishna, S. A review on polymer nanofibers by electrospinning and their applications in nanocomposites. Compos. Sci. Technol. 2003, 63, 2223-2253. [CrossRef]

6. Sill, T.J.; von Recum, H.A. Electrospinning: Applications in drug delivery and tissue engineering. Biomaterials 2008, 29, 1989-2006. [CrossRef] [PubMed]

7. Taylor, G. Electrically driven jets. Proc. R. Soc. Lond. A Math. Phys. Eng. Sci. 1969, 313, 453-475. [CrossRef]

8. Yarin, A.; Koombhongse, S.; Reneker, D.H. Bending instability in electrospinning of nanofibers. J. Appl. Phys. 2001, 89, 3018-3026. [CrossRef]

9. Doshi, J.; Reneker, D.H. Electrospinning process and applications of electrospun fibers. J. Electrost. 1995, 35, 154-160. [CrossRef]

10. Yang, Q.; Li, Z.; Hong, Y.; Zhao, Y.; Qiu, S.; Wang, C.; Wei, Y. Influence of solvents on the formation of ultrathin uniform poly(vinyl pyrrolidone) nanofibers with electrospinning. J. Polym. Sci. Part B Polym. Phys. 2004, 42, 3721-3726. [CrossRef]

11. Shin, Y.; Hohman, M.; Brenner, M.; Rutledge, G. Electrospinning: A whipping fluid jet generates submicron polymer fibers. Appl. Phys. Lett. 2001, 78, 1149-1151. [CrossRef]

12. Jaeger, R.; Bergshoef, M.M.; Batlle, C.M.I.; Schönherr, H.; Julius Vancso, G. Electrospinning of ultra-thin polymer fibers. Macromol. Symp. 1998, 127, 141-150. [CrossRef]

13. Carson, R.; Hendricks, C.; Hogan, J.; Schneider, J. Factors influencing electrically sprayed liquids. AIAA J. 1964, 2, 1460-1461. [CrossRef]

14. Buchko, C.J.; Chen, L.C.; Shen, Y.; Martin, D.C. Processing and microstructural characterization of porous biocompatible protein polymer thin films. Polymer 1999, 40, 7397-7407. [CrossRef]

15. Deitzel, J.; Kleinmeyer, J.; Harris, D.; Tan, N.B. The effect of processing variables on the morphology of electrospun nanofibers and textiles. Polymer 2001, 42, 261-272. [CrossRef]

16. Reneker, D.H.; Chun, I. Nanometre diameter fibres of polymer, produced by electrospinning. Nanotechnology 1996, 7, 216. [CrossRef]

17. Zhang, C.; Yuan, X.; Wu, L.; Han, Y.; Sheng, J. Study on morphology of electrospun poly(vinyl alcohol) mats. Eur. Polym. J. 2005, 41, 423-432. [CrossRef]

18. Li, Z.; Wang, C. Effects of working parameters on electrospinning. In One-Dimensional Nanostructures; Springer: Berlin, Germany, 2013; pp. 15-28.

19. Megelski, S.; Stephens, J.S.; Chase, D.B.; Rabolt, J.F. Micro-and nanostructured surface morphology on electrospun polymer fibers. Macromolecules 2002, 35, 8456-8466. [CrossRef] 
20. Kilic, A.; Oruc, F.; Demir, A. Effects of polarity on electrospinning process. Text. Res. J. 2008, 78, 532-539. [CrossRef]

21. Varesano, A.; Carletto, R.A.; Mazzuchetti, G. Experimental investigations on the multi-jet electrospinning process. J. Mater. Process. Technol. 2009, 209, 5178-5185. [CrossRef]

22. Zargham, S.; Bazgir, S.; Tavakoli, A.; Rashidi, A.S.; Damerchely, R. The effect of flow rate on morphology and deposition area of electrospun nylon 6 nanofiber. J. Eng. Fibers Fabr. 2012, 7, 42-49.

23. Bhardwaj, N.; Kundu, S.C. Electrospinning: A fascinating fiber fabrication technique. Biotechnol. Adv. 2010, 28, 325-347. [CrossRef] [PubMed]

24. Nurwaha, D.; Han, W.; Wang, X. Investigation of a new needleless electrospinning method for the production of nanofibers. J. Eng. Fibers Fabr. 2013, 8, 42-49.

25. Sukigara, S.; Gandhi, M.; Ayutsede, J.; Micklus, M.; Ko, F. Regeneration of Bombyx mori silk by electrospinning-Part 1: Processing parameters and geometric properties. Polymer 2003, 44, 5721-5727. [CrossRef]

26. Fong, H.; Chun, I.; Reneker, D. Beaded nanofibers formed during electrospinning. Polymer 1999, 40, 4585-4592. [CrossRef]

27. Baumgarten, P.K. Electrostatic spinning of acrylic microfibers. J. Colloid Interface Sci. 1971, 36, 71-79. [CrossRef]

28. Meechaisue, C.; Dubin, R.; Supaphol, P.; Hoven, V.P.; Kohn, J. Electrospun mat of tyrosine-derived polycarbonate fibers for potential use as tissue scaffolding material. J. Biomater. Sci. Polym. Ed. 2006, 17, 1039-1056. [CrossRef] [PubMed]

29. Koski, A.; Yim, K.; Shivkumar, S. Effect of molecular weight on fibrous PVA produced by electrospinning. Mater. Lett. 2004, 58, 493-497. [CrossRef]

30. Zhao, Y.; Yang, Q.; Lu, X.-F.; Wang, C.; Wei, Y. Study on correlation of morphology of electrospun products of polyacrylamide with ultrahigh molecular weight. J. Polym. Sci. Part B Polym. Phys. 2005, 43, 2190-2195. [CrossRef]

31. Lyons, J.; Li, C.; Ko, F. Melt-electrospinning part I: Processing parameters and geometric properties. Polymer 2004, 45, 7597-7603. [CrossRef]

32. Larrondo, L.; St John Manley, R. Electrostatic fiber spinning from polymer melts. I. Experimental observations on fiber formation and properties. J. Polym. Sci. Polym. Phys. Ed. 1981, 19, 909-920. [CrossRef]

33. Ding, B.; Kim, H.Y.; Lee, S.C.; Shao, C.L.; Lee, D.R.; Park, S.J.; Kwag, G.B.; Choi, K.J. Preparation and characterization of a nanoscale poly(vinyl alcohol) fiber aggregate produced by an electrospinning method. J. Polym. Sci. Part B Polym. Phys. 2002, 40, 1261-1268. [CrossRef]

34. Inai, R.; Kotaki, M.; Ramakrishna, S. Structure and properties of electrospun PLLA single nanofibres. Nanotechnology 2005, 16, 208. [CrossRef] [PubMed]

35. Kim, K.-H.; Jeong, L.; Park, H.-N.; Shin, S.-Y.; Park, W.-H.; Lee, S.-C.; Kim, T.-I.; Park, Y.-J.; Seol, Y.-J.; Lee, Y.-M. Biological efficacy of silk fibroin nanofiber membranes for guided bone regeneration. J. Biotechnol. 2005, 120, 327-339. [CrossRef] [PubMed]

36. Lee, J.S.; Choi, K.H.; Ghim, H.D.; Kim, S.S.; Chun, D.H.; Kim, H.Y.; Lyoo, W.S. Role of molecular weight of atactic poly(vinyl alcohol)(PVA) in the structure and properties of PVA nanofabric prepared by electrospinning. J. Appl. Polym. Sci. 2004, 93, 1638-1646. [CrossRef]

37. Pillay, V.; Dott, C.; Choonara, Y.E.; Tyagi, C.; Tomar, L.; Kumar, P.; du Toit, L.C.; Ndesendo, V.M. A review of the effect of processing variables on the fabrication of electrospun nanofibers for drug delivery applications. J. Nanomater. 2013, 2013. [CrossRef]

38. Zong, X.; Kim, K.; Fang, D.; Ran, S.; Hsiao, B.S.; Chu, B. Structure and process relationship of electrospun bioabsorbable nanofiber membranes. Polymer 2002, 43, 4403-4412. [CrossRef]

39. Hayati, I.; Bailey, A.; Tadros, T.F. Investigations into the mechanisms of electrohydrodynamic spraying of liquids: I. Effect of electric field and the environment on pendant drops and factors affecting the formation of stable jets and atomization. J. Colloid Interface Sci. 1987, 117, 205-221. [CrossRef]

40. Huang, C.; Chen, S.; Lai, C.; Reneker, D.H.; Qiu, H.; Ye, Y.; Hou, H. Electrospun polymer nanofibres with small diameters. Nanotechnology 2006, 17, 1558. [CrossRef] [PubMed]

41. Gupta, B.; Revagade, N.; Hilborn, J. Poly(lactic acid) fiber: An overview. Prog. Polym. Sci. 2007, 32, 455-482. [CrossRef] 
42. Cicero, J.A.; Dorgan, J.R.; Garrett, J.; Runt, J.; Lin, J. Effects of molecular architecture on two-step, melt-spun poly (lactic acid) fibers. J. Appl. Polym. Sci. 2002, 86, 2839-2846. [CrossRef]

43. Kim, M.S.; Kim, J.C.; Kim, Y.H. Effects of take-up speed on the structure and properties of melt-spun poly(L-lactic acid) fibers. Polym. Adv. Technol. 2008, 19, 748-755. [CrossRef]

44. Postema, A.; Luiten, A.; Pennings, A. High-strength poly(L-lactide) fibers by a dry-spinning/hot-drawing process. I. Influence of the ambient temperature on the dry-spinning process. J. Appl. Polym. Sci. 1990, 39, 1265-1274. [CrossRef]

45. Persano, L.; Camposeo, A.; Tekmen, C.; Pisignano, D. Industrial upscaling of electrospinning and applications of polymer nanofibers: A review. Macromol. Mater. Eng. 2013, 298, 504-520. [CrossRef]

46. Tan, E.; Ng, S.; Lim, C. Tensile testing of a single ultrafine polymeric fiber. Biomaterials 2005, 26, 1453-1456. [CrossRef] [PubMed]

47. Liu, J.; Shen, Z.; Lee, S.-H.; Marquez, M.; McHugh, M.A. Electrospinning in compressed carbon dioxide: Hollow or open-cell fiber formation with a single nozzle configuration. J. Supercrit. Fluids 2010, 53, 142-150. [CrossRef]

48. Stitzel, J.; Liu, J.; Lee, S.J.; Komura, M.; Berry, J.; Soker, S.; Lim, G.; Van Dyke, M.; Czerw, R.; Yoo, J.J. Controlled fabrication of a biological vascular substitute. Biomaterials 2006, 27, 1088-1094. [CrossRef] [PubMed]

49. Zhou, Y.; Freitag, M.; Hone, J.; Staii, C.; Johnson, A., Jr.; Pinto, N.J.; MacDiarmid, A. Fabrication and electrical characterization of polyaniline-based nanofibers with diameter below $30 \mathrm{~nm}$. Appl. Phys. Lett. 2003, 83, 3800-3802. [CrossRef]

50. Agarwal, S.; Burgard, M.; Greiner, A.; Wendorff, J. Electrospinning: A Practical Guide to Nanofibers; Walter de Gruyter GmbH \& Co KG: Berlin, Germany, 2016.

51. Gupta, P.; Wilkes, G.L. Some investigations on the fiber formation by utilizing a side-by-side bicomponent electrospinning approach. Polymer 2003, 44, 6353-6359. [CrossRef]

52. Townsend-Nicholson, A.; Jayasinghe, S.N. Cell electrospinning: A unique biotechnique for encapsulating living organisms for generating active biological microthreads/scaffolds. Biomacromolecules 2006, 7, 3364-3369. [CrossRef] [PubMed]

53. Ravichandran, R.; Venugopal, J.R.; Sundarrajan, S.; Mukherjee, S.; Sridhar, R.; Ramakrishna, S. Expression of cardiac proteins in neonatal cardiomyocytes on PGS/fibrinogen core/shell substrate for Cardiac tissue engineering. Int. J. Cardiol. 2013, 167, 1461-1468. [CrossRef] [PubMed]

54. Wang, X.; Yuan, Y.; Huang, X.; Yue, T. Controlled release of protein from core-shell nanofibers prepared by emulsion electrospinning based on green chemical. J. Appl. Polym. Sci. 2015, 132. [CrossRef]

55. Su, Y.; Su, Q.; Liu, W.; Lim, M.; Venugopal, J.R.; Mo, X.; Ramakrishna, S.; Al-Deyab, S.S.; El-Newehy, M. Controlled release of bone morphogenetic protein 2 and dexamethasone loaded in core-shell PLLACL-collagen fibers for use in bone tissue engineering. Acta Biomater. 2012, 8, 763-771. [CrossRef] [PubMed]

56. Rubert, M.; Dehli, J.; Li, Y.-F.; Taskin, M.B.; Xu, R.; Besenbacher, F.; Chen, M. Electrospun PCL/PEO coaxial fibers for basic fibroblast growth factor delivery. J. Mater. Chem. B 2014, 2, 8538-8546. [CrossRef]

57. Liao, I.; Chew, S.; Leong, K. Aligned core-shell nanofibers delivering bioactive proteins. Nanomedicine 2006, 1, 465-471. [CrossRef] [PubMed]

58. Tian, L.; Prabhakaran, M.P.; Ding, X.; Kai, D.; Ramakrishna, S. Emulsion electrospun vascular endothelial growth factor encapsulated poly(L-lactic acid-co- $\varepsilon$-caprolactone) nanofibers for sustained release in cardiac tissue engineering. J. Mater. Sci. 2012, 47, 3272-3281. [CrossRef]

59. Choi, J.S.; Choi, S.H.; Yoo, H.S. Coaxial electrospun nanofibers for treatment of diabetic ulcers with binary release of multiple growth factors. J. Mater. Chem. 2011, 21, 5258-5267. [CrossRef]

60. Liao, I.-C.; Chen, S.; Liu, J.B.; Leong, K.W. Sustained viral gene delivery through core-shell fibers. J. Control. Release 2009, 139, 48-55. [CrossRef] [PubMed]

61. Wang, C.; Yan, K.-W.; Lin, Y.-D.; Hsieh, P.C. Biodegradable core/shell fibers by coaxial electrospinning: Processing, fiber characterization, and its application in sustained drug release. Macromolecules 2010, 43, 6389-6397. [CrossRef]

62. Saraf, A.; Baggett, L.S.; Raphael, R.M.; Kasper, F.K.; Mikos, A.G. Regulated non-viral gene delivery from coaxial electrospun fiber mesh scaffolds. J. Control. Release 2010, 143, 95-103. [CrossRef] [PubMed]

63. Liao, I.-C.; Leong, K.W. Efficacy of engineered FVIII-producing skeletal muscle enhanced by growth factor-releasing co-axial electrospun fibers. Biomaterials 2011, 32, 1669-1677. [CrossRef] [PubMed] 
64. Huang, W.; Zou, T.; Li, S.; Jing, J.; Xia, X.; Liu, X. Drug-loaded zein nanofibers prepared using a modified coaxial electrospinning process. AAPS PharmSciTech 2013, 14, 675-681. [CrossRef] [PubMed]

65. Zhu, T.; Chen, S.; Li, W.; Lou, J.; Wang, J. Flurbiprofen axetil loaded coaxial electrospun poly (vinyl pyrrolidone)-nanopoly(lactic-co-glycolic acid) core-shell composite nanofibers: Preparation, characterization, and anti-adhesion activity. J. Appl. Polym. Sci. 2015, 132. [CrossRef]

66. Ignatova, M.; Rashkov, I.; Manolova, N. Drug-loaded electrospun materials in wound-dressing applications and in local cancer treatment. Expert Opin. Drug Deliv. 2013, 10, 469-483. [CrossRef] [PubMed]

67. Ding, B.; Kimura, E.; Sato, T.; Fujita, S.; Shiratori, S. Fabrication of blend biodegradable nanofibrous nonwoven mats via multi-jet electrospinning. Polymer 2004, 45, 1895-1902. [CrossRef]

68. Theron, S.; Yarin, A.; Zussman, E.; Kroll, E. Multiple jets in electrospinning: Experiment and modeling. Polymer 2005, 46, 2889-2899. [CrossRef]

69. Teo, W.; Ramakrishna, S. Electrospun fibre bundle made of aligned nanofibres over two fixed points. Nanotechnology 2005, 16, 1878. [CrossRef]

70. Kim, G.; Cho, Y.-S.; Kim, W.D. Stability analysis for multi-jets electrospinning process modified with a cylindrical electrode. Eur. Polym. J. 2006, 42, 2031-2038. [CrossRef]

71. Hong, Y.; Fujimoto, K.; Hashizume, R.; Guan, J.; Stankus, J.J.; Tobita, K.; Wagner, W.R. Generating elastic, biodegradable polyurethane/poly(lactide-co-glycolide) fibrous sheets with controlled antibiotic release via two-stream electrospinning. Biomacromolecules 2008, 9, 1200-1207. [CrossRef] [PubMed]

72. Wang, X.; Um, I.C.; Fang, D.; Okamoto, A.; Hsiao, B.S.; Chu, B. Formation of water-resistant hyaluronic acid nanofibers by blowing-assisted electro-spinning and non-toxic post treatments. Polymer 2005, 46, 4853-4867. [CrossRef]

73. Sundaray, B.; Subramanian, V.; Natarajan, T.; Xiang, R.-Z.; Chang, C.-C.; Fann, W.-S. Electrospinning of continuous aligned polymer fibers. Appl. Phys. Lett. 2004, 84, 1222-1224. [CrossRef]

74. Li, D.; Wang, Y.; Xia, Y. Electrospinning nanofibers as uniaxially aligned arrays and layer-by-layer stacked films. Adv. Mater. 2004, 16, 361-366. [CrossRef]

75. Ki, C.S.; Kim, J.W.; Hyun, J.H.; Lee, K.H.; Hattori, M.; Rah, D.K.; Park, Y.H. Electrospun three-dimensional silk fibroin nanofibrous scaffold. J. Appl. Polym. Sci. 2007, 106, 3922-3928. [CrossRef]

76. Smit, E.; Búttner, U.; Sanderson, R.D. Continuous yarns from electrospun fibers. Polymer 2005, 46, 2419-2423. [CrossRef]

77. Xu, C.; Inai, R.; Kotaki, M.; Ramakrishna, S. Aligned biodegradable nanofibrous structure: A potential scaffold for blood vessel engineering. Biomaterials 2004, 25, 877-886. [CrossRef]

78. Bazilevsky, A.V.; Yarin, A.L.; Megaridis, C.M. Co-electrospinning of core-shell fibers using a single-nozzle technique. Langmuir 2007, 23, 2311-2314. [CrossRef] [PubMed]

79. Bhattarai, N.; Edmondson, D.; Veiseh, O.; Matsen, F.A.; Zhang, M. Electrospun chitosan-based nanofibers and their cellular compatibility. Biomaterials 2005, 26, 6176-6184. [CrossRef] [PubMed]

80. Theron, A.; Zussman, E.; Yarin, A. Electrostatic field-assisted alignment of electrospun nanofibres. Nanotechnology 2001, 12, 384. [CrossRef]

81. Zeng, J.; Yang, L.; Liang, Q.; Zhang, X.; Guan, H.; Xu, X.; Chen, X.; Jing, X. Influence of the drug compatibility with polymer solution on the release kinetics of electrospun fiber formulation. J. Control. Release 2005, 105, 43-51. [CrossRef] [PubMed]

82. Meng, Z.; Xu, X.; Zheng, W.; Zhou, H.; Li, L.; Zheng, Y.; Lou, X. Preparation and characterization of electrospun PLGA/gelatin nanofibers as a potential drug delivery system. Colloids Surf. B Biointerfaces 2011, 84, 97-102. [CrossRef] [PubMed]

83. Kim, K.; Luu, Y.K.; Chang, C.; Fang, D.; Hsiao, B.S.; Chu, B.; Hadjiargyrou, M. Incorporation and controlled release of a hydrophilic antibiotic using poly(lactide-co-glycolide)-based electrospun nanofibrous scaffolds. J. Control. Release 2004, 98, 47-56. [CrossRef] [PubMed]

84. Jannesari, M.; Varshosaz, J.; Morshed, M.; Zamani, M. Composite poly (vinyl alcohol)/poly (vinyl acetate) electrospun nanofibrous mats as a novel wound dressing matrix for controlled release of drugs. Int. J. Nanomed. 2011, 6, 993-1003.

85. Nair, R.; Arunkumar, K.; Vishnu Priya, K.; Sevukarajan, M. Recent advances in solid lipid nanoparticle based drug delivery systems. J. Biomed. Sci. Res. 2011, 3, 368-384. 
86. Mickova, A.; Buzgo, M.; Benada, O.; Rampichova, M.; Fisar, Z.; Filova, E.; Tesarova, M.; Lukas, D.; Amler, E. Core/shell nanofibers with embedded liposomes as a drug delivery system. Biomacromolecules 2012, 13, 952-962. [CrossRef] [PubMed]

87. Volpato, F.Z.; Almodóvar, J.; Erickson, K.; Popat, K.C.; Migliaresi, C.; Kipper, M.J. Preservation of FGF-2 bioactivity using heparin-based nanoparticles, and their delivery from electrospun chitosan fibers. Acta Biomater. 2012, 8, 1551-1559. [CrossRef] [PubMed]

88. Kim, H.S.; Yoo, H.S. MMPs-responsive release of DNA from electrospun nanofibrous matrix for local gene therapy: In vitro and in vivo evaluation. J. Control. Release 2010, 145, 264-271. [CrossRef] [PubMed]

89. Mottaghitalab, F.; Farokhi, M.; Mottaghitalab, V.; Ziabari, M.; Divsalar, A.; Shokrgozar, M.A. Enhancement of neural cell lines proliferation using nano-structured chitosan/poly(vinyl alcohol) scaffolds conjugated with nerve growth factor. Carbohydr. Polym. 2011, 86, 526-535. [CrossRef]

90. Choi, J.S.; Leong, K.W.; Yoo, H.S. In vivo wound healing of diabetic ulcers using electrospun nanofibers immobilized with human epidermal growth factor (EGF). Biomaterials 2008, 29, 587-596. [CrossRef] [PubMed]

91. Im, J.S.; Yun, J.; Lim, Y.-M.; Kim, H.-I.; Lee, Y.-S. Fluorination of electrospun hydrogel fibers for a controlled release drug delivery system. Acta Biomater. 2010, 6, 102-109. [CrossRef] [PubMed]

92. Yun, J.; Im, J.S.; Lee, Y.-S.; Kim, H.-I. Electro-responsive transdermal drug delivery behavior of PVA/PAA/MWCNT nanofibers. Eur. Polym. J. 2011, 47, 1893-1902. [CrossRef]

93. Kim, H.; Yoo, H. Matrix metalloproteinase-inspired suicidal treatments of diabetic ulcers with siRNAdecorated nanofibrous meshes. Gene Ther. 2013, 20, 378-385. [CrossRef] [PubMed]

94. Luu, Y.; Kim, K.; Hsiao, B.; Chu, B.; Hadjiargyrou, M. Development of a nanostructured DNA delivery scaffold via electrospinning of PLGA and PLA-PEG block copolymers. J. Control. Release 2003, 89, 341-353. [CrossRef]

95. Zamani, M.; Prabhakaran, M.P.; Ramakrishna, S. Advances in drug delivery via electrospun and electrosprayed nanomaterials. Int. J. Nanomed. 2013, 8, 2997-3017.

96. Xu, X.; Yang, L.; Xu, X.; Wang, X.; Chen, X.; Liang, Q.; Zeng, J.; Jing, X. Ultrafine medicated fibers electrospun from W/O emulsions. J. Control. Release 2005, 108, 33-42. [CrossRef] [PubMed]

97. Yang, Y.; Li, X.; Qi, M.; Zhou, S.; Weng, J. Release pattern and structural integrity of lysozyme encapsulated in core-sheath structured poly(DL-lactide) ultrafine fibers prepared by emulsion electrospinning. Eur. J. Pharm. Biopharm. 2008, 69, 106-116. [CrossRef] [PubMed]

98. He, S.; Xia, T.; Wang, H.; Wei, L.; Luo, X.; Li, X. Multiple release of polyplexes of plasmids VEGF and bFGF from electrospun fibrous scaffolds towards regeneration of mature blood vessels. Acta Biomater. 2012, 8 , 2659-2669. [CrossRef] [PubMed]

99. Yang, Y.; Li, X.; Cheng, L.; He, S.; Zou, J.; Chen, F.; Zhang, Z. Core-sheath structured fibers with pDNA polyplex loadings for the optimal release profile and transfection efficiency as potential tissue engineering scaffolds. Acta Biomater. 2011, 7, 2533-2543. [CrossRef] [PubMed]

100. Wang, Y.; Qiao, W.; Yin, T. A novel controlled release drug delivery system for multiple drugs based on electrospun nanofibers containing nanoparticles. J. Pharm. Sci. 2010, 99, 4805-4811. [CrossRef] [PubMed]

101. Xu, J.; Jiao, Y.; Shao, X.; Zhou, C. Controlled dual release of hydrophobic and hydrophilic drugs from electrospun poly(L-lactic acid) fiber mats loaded with chitosan microspheres. Mater. Lett. 2011, 65, 2800-2803. [CrossRef]

102. Okuda, T.; Tominaga, K.; Kidoaki, S. Time-programmed dual release formulation by multilayered drug-loaded nanofiber meshes. J. Control. Release 2010, 143, 258-264. [CrossRef] [PubMed]

103. Chunder, A.; Sarkar, S.; Yu, Y.; Zhai, L. Fabrication of ultrathin polyelectrolyte fibers and their controlled release properties. Colloids Surf. B Biointerfaces 2007, 58, 172-179. [CrossRef] [PubMed]

104. Im, J.S.; Lee, S.K.; Bai, B.C.; Lee, Y.-S. Prediction and characterization of drug release in a multi-drug release system. J. Ind. Eng. Chem. 2012, 18, 325-330. [CrossRef]

105. Prausnitz, M.R.; Langer, R. Transdermal drug delivery. Nat. Biotechnol. 2008, 26, 1261-1268. [CrossRef] [PubMed]

106. Suwantong, O.; Ruktanonchai, U.; Supaphol, P. Electrospun cellulose acetate fiber mats containing asiaticoside or Centella asiatica crude extract and the release characteristics of asiaticoside. Polymer 2008, 49, 4239-4247. [CrossRef]

107. Taepaiboon, P.; Rungsardthong, U.; Supaphol, P. Drug-loaded electrospun mats of poly (vinyl alcohol) fibres and their release characteristics of four model drugs. Nanotechnology 2006, 17, 2317. [CrossRef] 
108. Suwantong, O.; Opanasopit, P.; Ruktanonchai, U.; Supaphol, P. Electrospun cellulose acetate fiber mats containing curcumin and release characteristic of the herbal substance. Polymer 2007, 48, 7546-7557. [CrossRef]

109. Im, J.S.; Bai, B.C.; Lee, Y.-S. The effect of carbon nanotubes on drug delivery in an electro-sensitive transdermal drug delivery system. Biomaterials 2010, 31, 1414-1419. [CrossRef] [PubMed]

110. Taepaiboon, P.; Rungsardthong, U.; Supaphol, P. Vitamin-loaded electrospun cellulose acetate nanofiber mats as transdermal and dermal therapeutic agents of vitamin A acid and vitamin E. Eur. J. Pharm. Biopharm. 2007, 67, 387-397. [CrossRef] [PubMed]

111. Ngawhirunpat, T.; Opanasopit, P.; Rojanarata, T.; Akkaramongkolporn, P.; Ruktanonchai, U.; Supaphol, P. Development of meloxicam-loaded electrospun polyvinyl alcohol mats as a transdermal therapeutic agent. Pharm. Dev. Technol. 2009, 14, 73-82. [CrossRef] [PubMed]

112. Reda, R.I.; Wen, M.M.; El-Kamel, A.H. Ketoprofen-loaded eudragit electrospun nanofibers for the treatment of oral mucositis. Int. J. Nanomed. 2017, 12, 2335. [CrossRef] [PubMed]

113. Kenawy, E.-R.; Bowlin, G.L.; Mansfield, K.; Layman, J.; Simpson, D.G.; Sanders, E.H.; Wnek, G.E. Release of tetracycline hydrochloride from electrospun poly(ethylene-co-vinylacetate), poly (lactic acid), and a blend. J. Control. Release 2002, 81, 57-64. [CrossRef]

114. Alhusein, N.; Blagbrough, I.S.; De Bank, P.A. Electrospun matrices for localised controlled drug delivery: Release of tetracycline hydrochloride from layers of polycaprolactone and poly(ethylene-co-vinyl acetate). Drug Deliv. Transl. Res. 2012, 2, 477-488. [CrossRef] [PubMed]

115. Alhusein, N.; De Bank, P.A.; Blagbrough, I.S.; Bolhuis, A. Killing bacteria within biofilms by sustained release of tetracycline from triple-layered electrospun micro/nanofibre matrices of polycaprolactone and poly (ethylene-co-vinyl acetate). Drug Deliv. Transl. Res. 2013, 3, 531-541. [CrossRef] [PubMed]

116. Wang, X.; Yue, T.; Lee, T.-C. Development of Pleurocidin-poly(vinyl alcohol) electrospun antimicrobial nanofibers to retain antimicrobial activity in food system application. Food Control 2015, 54, 150-157. [CrossRef]

117. Zhang, Y.; Lim, C.T.; Ramakrishna, S.; Huang, Z.-M. Recent development of polymer nanofibers for biomedical and biotechnological applications. J. Mater. Sci. Mater. Med. 2005, 16, 933-946. [CrossRef] [PubMed]

118. Boateng, J.S.; Matthews, K.H.; Stevens, H.N.; Eccleston, G.M. Wound healing dressings and drug delivery systems: A review. J. Pharm. Sci. 2008, 97, 2892-2923. [CrossRef] [PubMed]

119. Said, S.S.; Aloufy, A.K.; El-Halfawy, O.M.; Boraei, N.A.; El-Khordagui, L.K. Antimicrobial PLGA ultrafine fibers: Interaction with wound bacteria. Eur. J. Pharm. Biopharm. 2011, 79, 108-118. [CrossRef] [PubMed]

120. Thakur, R.; Florek, C.; Kohn, J.; Michniak, B. Electrospun nanofibrous polymeric scaffold with targeted drug release profiles for potential application as wound dressing. Int. J. Pharm. 2008, 364, 87-93. [CrossRef] [PubMed]

121. Wang, A.; Xu, C.; Zhang, C.; Gan, Y.; Wang, B. Experimental investigation of the properties of electrospun nanofibers for potential medical application. J. Nanomater. 2015, 2015, 5. [CrossRef]

122. GhavamiNejad, A.; Rajan Unnithan, A.; Ramachandra Kurup Sasikala, A.; Samarikhalaj, M.; Thomas, R.G.; Jeong, Y.Y.; Nasseri, S.; Murugesan, P.; Wu, D.; Hee Park, C. Mussel-inspired electrospun nanofibers functionalized with size-controlled silver nanoparticles for wound dressing application. ACS Appl. Mater. Interfaces 2015, 7, 12176-12183. [CrossRef] [PubMed]

123. Chutipakdeevong, J.; Ruktanonchai, U.; Supaphol, P. Hybrid biomimetic electrospun fibrous mats derived from poly(e-caprolactone) and silk fibroin protein for wound dressing application. J. Appl. Polym. Sci. 2015, 132, 41653. [CrossRef]

124. Xu, X.; Chen, X.; Ma, P.; Wang, X.; Jing, X. The release behavior of doxorubicin hydrochloride from medicated fibers prepared by emulsion-electrospinning. Eur. J. Pharm. Biopharm. 2008, 70, 165-170. [CrossRef] [PubMed]

125. Xu, X.; Chen, X.; Wang, Z.; Jing, X. Ultrafine PEG-PLA fibers loaded with both paclitaxel and doxorubicin hydrochloride and their in vitro cytotoxicity. Eur. J. Pharm. Biopharm. 2009, 72, 18-25. [CrossRef] [PubMed]

126. Xie, J.; Tan, R.S.; Wang, C.H. Biodegradable microparticles and fiber fabrics for sustained delivery of cisplatin to treat C6 glioma in vitro. J. Biomed. Mater. Res. Part A 2008, 85, 897-908. [CrossRef] [PubMed] 
127. Liu, S.; Zhou, G.; Liu, D.; Xie, Z.; Huang, Y.; Wang, X.; Wu, W.; Jing, X. Inhibition of orthotopic secondary hepatic carcinoma in mice by doxorubicin-loaded electrospun polylactide nanofibers. J. Mater. Chem. B 2013, 1, 101-109. [CrossRef]

128. Luo, X.; Xie, C.; Wang, H.; Liu, C.; Yan, S.; Li, X. Antitumor activities of emulsion electrospun fibers with core loading of hydroxycamptothecin via intratumoral implantation. Int. J. Pharm. 2012, 425, 19-28. [CrossRef] [PubMed]

129. Gupta, S. Biocompatible microemulsion systems for drug encapsulation and delivery. Curr Sci 2011, 101, 174-188.

130. Chen, P.; Wu, Q.-S.; Ding, Y.-P.; Chu, M.; Huang, Z.-M.; Hu, W. A controlled release system of titanocene dichloride by electrospun fiber and its antitumor activity in vitro. Eur. J. Pharm. Biopharm. 2010, 76, 413-420. [CrossRef] [PubMed]

131. Shao, S.; Li, L.; Yang, G.; Li, J.; Luo, C.; Gong, T.; Zhou, S. Controlled green tea polyphenols release from electrospun PCL/MWCNTs composite nanofibers. Int. J. Pharm. 2011, 421, 310-320. [CrossRef] [PubMed]

132. Zahedi, P.; Karami, Z.; Rezaeian, I.; Jafari, S.H.; Mahdaviani, P.; Abdolghaffari, A.H.; Abdollahi, M. Preparation and performance evaluation of tetracycline hydrochloride loaded wound dressing mats based on electrospun nanofibrous poly(lactic acid)/poly(e-caprolactone) blends. J. Appl. Polym. Sci. 2012, 124, 4174-4183. [CrossRef]

133. He, C.L.; Huang, Z.M.; Han, X.J.; Liu, L.; Zhang, H.S.; Chen, L.S. Coaxial electrospun poly(L-lactic acid) ultrafine fibers for sustained drug delivery. J. Macromol. Sci. Part B 2006, 45, 515-524. [CrossRef]

134. He, C.L.; Huang, Z.M.; Han, X.J. Fabrication of drug-loaded electrospun aligned fibrous threads for suture applications. J. Biomed. Mater. Res. Part A 2009, 89, 80-95. [CrossRef] [PubMed]

135. Gilchrist, S.E.; Lange, D.; Letchford, K.; Bach, H.; Fazli, L.; Burt, H.M. Fusidic acid and rifampicin co-loaded PLGA nanofibers for the prevention of orthopedic implant associated infections. J. Control. Release 2013, 170, 64-73. [CrossRef] [PubMed]

136. Zamani, M.; Morshed, M.; Varshosaz, J.; Jannesari, M. Controlled release of metronidazole benzoate from poly $\varepsilon$-caprolactone electrospun nanofibers for periodontal diseases. Eur. J. Pharm. Biopharm. 2010, 75, 179-185. [CrossRef] [PubMed]

137. Toncheva, A.; Paneva, D.; Maximova, V.; Manolova, N.; Rashkov, I. Antibacterial fluoroquinolone antibiotic-containing fibrous materials from poly (L-lactide-co-D, L-lactide) prepared by electrospinning. Eur. J. Pharm. Sci. 2012, 47, 642-651. [CrossRef] [PubMed]

138. Spasova, M.; Manolova, N.; Paneva, D.; Rashkov, I. Preparation of chitosan-containing nanofibres by electrospinning of chitosan/poly(ethylene oxide) blend solutions. e-Polymers 2004, 4, 624-635. [CrossRef]

139. Verreck, G.; Chun, I.; Rosenblatt, J.; Peeters, J.; Van Dijck, A.; Mensch, J.; Noppe, M.; Brewster, M.E. Incorporation of drugs in an amorphous state into electrospun nanofibers composed of a water-insoluble, nonbiodegradable polymer. J. Control. Release 2003, 92, 349-360. [CrossRef]

140. Huang, L.-Y.; Branford-White, C.; Shen, X.-X.; Yu, D.-G.; Zhu, L.-M. Time-engineeringed biphasic drug release by electrospun nanofiber meshes. Int. J. Pharm. 2012, 436, 88-96. [CrossRef] [PubMed]

141. Jiang, Y.-N.; Mo, H.-Y.; Yu, D.-G. Electrospun drug-loaded core-sheath PVP/zein nanofibers for biphasic drug release. Int. J. Pharm. 2012, 438, 232-239. [CrossRef] [PubMed]

142. Jiang, H.; Fang, D.; Hsiao, B.; Chu, B.; Chen, W. Preparation and characterization of ibuprofen-loaded poly(lactide-co-glycolide)/poly(ethylene glycol)-g-chitosan electrospun membranes. J. Biomater. Sci. Polym. Ed. 2004, 15, 279-296. [CrossRef] [PubMed]

143. Lu, T.; Jing, X.; Song, X.; Wang, X. Doxorubicin-loaded ultrafine PEG-PLA fiber mats against hepatocarcinoma. J. Appl. Polym. Sci. 2012, 123, 209-217. [CrossRef]

144. Ranganath, S.H.; Wang, C.-H. Biodegradable microfiber implants delivering paclitaxel for post-surgical chemotherapy against malignant glioma. Biomaterials 2008, 29, 2996-3003. [CrossRef] [PubMed]

145. Xie, J.; Wang, C.-H. Electrospun micro-and nanofibers for sustained delivery of paclitaxel to treat C6 glioma in vitro. Pharm. Res. 2006, 23, 1817-1826. [CrossRef] [PubMed]

146. Liu, D.; Liu, S.; Jing, X.; Li, X.; Li, W.; Huang, Y. Necrosis of cervical carcinoma by dichloroacetate released from electrospun polylactide mats. Biomaterials 2012, 33, 4362-4369. [CrossRef] [PubMed]

147. Xu, X.; Zhuang, X.; Chen, X.; Wang, X.; Yang, L.; Jing, X. Preparation of core-sheath composite nanofibers by emulsion electrospinning. Macromol. Rapid Commun. 2006, 27, 1637-1642. [CrossRef] 
148. Chew, S.Y.; Wen, J.; Yim, E.K.; Leong, K.W. Sustained release of proteins from electrospun biodegradable fibers. Biomacromolecules 2005, 6, 2017-2024. [CrossRef] [PubMed]

149. Rujitanaroj, P.-o.; Wang, Y.-C.; Wang, J.; Chew, S.Y. Nanofiber-mediated controlled release of siRNA complexes for long term gene-silencing applications. Biomaterials 2011, 32, 5915-5923. [CrossRef] [PubMed]

150. Cao, H.; Jiang, X.; Chai, C.; Chew, S.Y. RNA interference by nanofiber-based siRNA delivery system. J. Control. Release 2010, 144, 203-212. [CrossRef] [PubMed]

151. Schneider, A.; Wang, X.; Kaplan, D.; Garlick, J.; Egles, C. Biofunctionalized electrospun silk mats as a topical bioactive dressing for accelerated wound healing. Acta Biomater. 2009, 5, 2570-2578. [CrossRef] [PubMed]

152. Zhang, X.; Shi, Z.; Fu, W.; Liu, Z.; Fang, Z.; Lu, W.; Wang, Y.; Chen, F. In vitro biocompatibility study of electrospun copolymer ethylene carbonate- $\varepsilon$-caprolactone and vascular endothelial growth factor blended nanofibrous scaffolds. Appl. Surf. Sci. 2012, 258, 2301-2306. [CrossRef]

153. Cho, Y.I.; Choi, J.S.; Jeong, S.Y.; Yoo, H.S. Nerve growth factor (NGF)-conjugated electrospun nanostructures with topographical cues for neuronal differentiation of mesenchymal stem cells. Acta Biomater. 2010, 6, 4725-4733. [CrossRef] [PubMed]

154. Han, N.; Johnson, J.; Lannutti, J.J.; Winter, J.O. Hydrogel-electrospun fiber composite materials for hydrophilic protein release. J. Control. Release 2012, 158, 165-170. [CrossRef] [PubMed]

155. Chen, G.; Lv, Y. Immobilization and application of electrospun nanofiber scaffold-based growth factor in bone tissue engineering. Curr. Pharm. Des. 2015, 21, 1967-1978. [CrossRef] [PubMed]

156. Ren, S.; Dong, L.; Zhang, X.; Lei, T.; Ehrenhauser, F.; Song, K.; Li, M.; Sun, X.; Wu, Q. Electrospun Nanofibers Made of Silver Nanoparticles, Cellulose Nanocrystals, and Polyacrylonitrile as Substrates for Surface-Enhanced Raman Scattering. Materials 2017, 10, 68. [CrossRef] [PubMed]

157. Segala, K.; Nista, S.V.G.; Cordi, L.; Bizarria, M.T.M.; Ávila Júnior, J.D.; Kleinubing, S.A.; Cruz, D.C.; Brocchi, M.; Lona, L.M.F.; Caballero, N.E.D. Silver nanoparticles incorporated into nanostructured biopolymer membranes produced by electrospinning: A study of antimicrobial activity. Braz. J. Pharm. Sci. 2015, 51, 911-921. [CrossRef]

158. Li, J.; Chen, X.; Ai, N.; Hao, J.; Chen, Q.; Strauf, S.; Shi, Y. Silver nanoparticle doped $\mathrm{TiO}_{2}$ nanofiber dye sensitized solar cells. Chem. Phys. Lett. 2011, 514, 141-145. [CrossRef]

159. Cui, H.; Yuan, L.; Li, W.; Lin, L. Antioxidant property of $\mathrm{SiO}_{2}$-eugenol liposome loaded nanofibrous membranes on beef. Food Packag. Shelf Life 2017, 11, 49-57. [CrossRef]

160. Yarin, A.L.; Pourdeyhimi, B.; Ramakrishna, S. Fundamentals and Applications of Micro-and Nanofibers; Cambridge University Press: Cambridge, UK, 2014.

161. Zou, H.; Lv, P.F.; Wang, X.; Wu, D.; Yu, D.G. Electrospun poly(2-aminothiazole)/cellulose acetate fiber membrane for removing $\mathrm{Hg}$ (II) from water. J. Appl. Polym. Sci. 2017, 134. [CrossRef]

162. Zhou, J.; Zhang, J.; Rehman, A.U.; Kan, K.; Li, L.; Shi, K. Synthesis, characterization, and ammonia gas sensing properties of $\mathrm{Co}_{3} \mathrm{O}_{4} @ \mathrm{CuO}$ nanochains. J. Mater Sci. 2016, 52, 1-14. [CrossRef]

163. Homaeigohar, S.; Elbahri, M. Nanocomposite electrospun nanofiber membranes for environmental remediation. Materials 2014, 7, 1017-1045. [CrossRef] [PubMed]

164. Lee, S.J.; Heo, D.N.; Moon, J.-H.; Ko, W.-K.; Lee, J.B.; Bae, M.S.; Park, S.W.; Kim, J.E.; Lee, D.H.; Kim, E.-C. Electrospun chitosan nanofibers with controlled levels of silver nanoparticles. Preparation, characterization and antibacterial activity. Carbohydr. Polym. 2014, 111, 530-537. [CrossRef] [PubMed]

165. Shi, Q.; Vitchuli, N.; Nowak, J.; Caldwell, J.M.; Breidt, F.; Bourham, M.; Zhang, X.; McCord, M. Durable antibacterial Ag/polyacrylonitrile (Ag/PAN) hybrid nanofibers prepared by atmospheric plasma treatment and electrospinning. Eur. Polym. J. 2011, 47, 1402-1409. [CrossRef]

166. Castro-Mayorga, J.; Randazzo, W.; Fabra, M.; Lagaron, J.; Aznar, R.; Sánchez, G. Antiviral properties of silver nanoparticles against norovirus surrogates and their efficacy in coated polyhydroxyalkanoates systems. LWT Food Sci. Technol. 2017, 79, 503-510. [CrossRef]

167. Nie, H.; Wang, C.-H. Fabrication and characterization of PLGA/HAp composite scaffolds for delivery of BMP-2 plasmid DNA. J. Control. Release 2007, 120, 111-121. [CrossRef] [PubMed]

168. Tanaka, K.; Shiga, T.; Katayama, T. Fabrication of Hydroxyapatite/PLA Composite Nanofiber by Electrospinning. WIT Trans. Built Environ. 2016, 166, 371-379.

169. Chen, M.; Gao, S.; Dong, M.; Song, J.; Yang, C.; Howard, K.A.; Kjems, J.; Besenbacher, F. Chitosan/siRNA nanoparticles encapsulated in PLGA nanofibers for siRNA delivery. ACS Nano 2012, 6, 4835-4844. [CrossRef] [PubMed] 
170. Chew, S.Y.; Mi, R.; Hoke, A.; Leong, K.W. Aligned Protein-Polymer Composite Fibers Enhance Nerve Regeneration: A Potential Tissue-Engineering Platform. Adv. Funct. Mater. 2007, 17, 1288-1296. [CrossRef] [PubMed]

171. Kowalczyk, T.; Nowicka, A.; Elbaum, D.; Kowalewski, T.A. Electrospinning of bovine serum albumin. Optimization and the use for production of biosensors. Biomacromolecules 2008, 9, 2087-2090. [CrossRef] [PubMed]

172. Li, X.; Su, Y.; Liu, S.; Tan, L.; Mo, X.; Ramakrishna, S. Encapsulation of proteins in poly (L-lactide-co-caprolactone) fibers by emulsion electrospinning. Colloids Surf. B Biointerfaces 2010, 75, 418-424. [CrossRef] [PubMed]

173. Huang, L.; Apkarian, R.P.; Chaikof, E.L. High-resolution analysis of engineered type I collagen nanofibers by electron microscopy. Scanning 2001, 23, 372-375. [CrossRef] [PubMed]

174. Huang, L.; Nagapudi, K.; Apkarian, R.P.; Chaikof, E.L. Engineered collagen-PEO nanofibers and fabrics. J. Biomater. Sci. Polym. Ed. 2001, 12, 979-993. [CrossRef] [PubMed]

175. Zhang, E.; Zhu, C.; Yang, J.; Sun, H.; Zhang, X.; Li, S.; Wang, Y.; Sun, L.; Yao, F. Electrospun PDLLA/PLGA composite membranes for potential application in guided tissue regeneration. Mater. Sci. Eng. C 2016, 58, 278-285. [CrossRef] [PubMed]

176. Sudakaran, S.V.; Venugopal, J.R.; Vijayakumar, G.P.; Abisegapriyan, S.; Grace, A.N.; Ramakrishna, S. Sequel of $\mathrm{MgO}$ nanoparticles in PLACL nanofibers for anti-cancer therapy in synergy with curcumin/ $\beta$-cyclodextrin. Mater. Sci. Eng. C 2017, 71, 620-628. [CrossRef] [PubMed]

177. Khalil, I.S.; Abdel-Kader, R.M.; Gomaa, I.E.; Serag, N.; Klingner, A.; Elwi, M. Targeting of Cancer Cells using Controlled Nanoparticles and Robotics Sperms. Int. J. Adv. Robot. Syst. 2016, 13, 123. [CrossRef]

178. Sezer, U.A.; Ozturk, K.; Aru, B.; Demirel, G.Y.; Sezer, S.; Bozkurt, M.R. Zero valent zinc nanoparticles promote neuroglial cell proliferation: A biodegradable and conductive filler candidate for nerve regeneration. J. Mater. Sci. Mater. Med. 2017, 28, 19. [CrossRef] [PubMed]

179. Kuchler-Bopp, S.; Larrea, A.; Petry, L.; Idoux-Gillet, Y.; Sebastian, V.; Ferrandon, A.; Schwinté, P.; Arruebo, M.; Benkirane-Jessel, N. Promoting Bioengineered Tooth Innervation Using Nanostructured and Hybrid Scaffolds. Acta Biomater. 2017, 50, 493-501. [CrossRef] [PubMed]

180. Teo, W.-E. Addressing the Needs of Nanofiber Mass Production (Limitation of Nozzle System). Available online: http:/ / electrospintech.com/mpchallenge.html\#.WK2nq28rLIX (accessed on 27 October 2018).

181. Li, L.; Frey, M.W.; Green, T.B. Modification of air filter media with nylon-6 nanofibers. J. Eng. Fibers Fabr. 2006, 1, 1-22.

182. Moon, S.; Gil, M.; Lee, K.J. Syringeless Electrospinning toward Versatile Fabrication of Nanofiber Web. Sci. Rep. 2017, 7, 41424. [CrossRef] [PubMed]

183. Liu, W.; Huang, C.; Jin, X. Electrospinning of grooved polystyrene fibers: Effect of solvent systems. Nanoscale Res. Lett. 2015, 10, 237. [CrossRef] [PubMed]

184. Zhang, B.; Yan, X.; He, H.-W.; Yu, M.; Ning, X.; Long, Y.-Z. Solvent-free electrospinning: Opportunities and challenges. Polym. Chem. 2017, 8, 333-352. [CrossRef]

185. Fakirov, S. Nano-Size Polymers: Preparation, Properties, Applications; Springer: Berlin, Germany, 2016.

186. Niu, H.; Lin, T. Fiber generators in needleless electrospinning. J. Nanomater. 2012, 12. [CrossRef]

187. Niu, H.; Lin, T.; Wang, X. Needleless electrospinning. I. A comparison of cylinder and disk nozzles. J. Appl. Polym. Sci. 2009, 114, 3524-3530. [CrossRef]

188. Cengiz, F.; Dao, T.A.; Jirsak, O. Influence of solution properties on the roller electrospinning of poly(vinyl alcohol). Polym. Eng. Sci. 2010, 50, 936-943. [CrossRef]

189. Niu, H.; Wang, X.; Lin, T. Needleless electrospinning: Influences of fibre generator geometry. J. Text. Inst. 2012, 103, 787-794. [CrossRef]

190. Liu, Y.; He, J. Bubble electrospinning for mass production of nanofibers. Int. J. Nonlinear Sci. Numer. Simul. 2007, 8, 393. [CrossRef]

191. Weng, L.; Xie, J. Smart electrospun nanofibers for controlled drug release: Recent advances and new perspectives. Curr. Pharm. Des. 2015, 21, 1944-1959. [CrossRef] [PubMed]

(C) 2018 by the authors. Licensee MDPI, Basel, Switzerland. This article is an open access article distributed under the terms and conditions of the Creative Commons Attribution (CC BY) license (http:/ / creativecommons.org/licenses/by/4.0/). 